\title{
Dressing up for Diffusion: Codes of Conduct in the German Textile and Apparel Industry, 1997-2010
}

\author{
Florian Scheiber
}

Received: 29 June 2012/ Accepted: 5 November 2013

(C) Springer Science+Business Media Dordrecht 2013

\begin{abstract}
I study the diffusion of codes of conduct in the German textile and apparel industry between 1997 and 2010. Using a longitudinal case study design, I aim to understand how the diffusion of this practice was affected by the way important "infomediaries"- a trade journal and a professional association-shaped its understanding within the industry. My results show that time-consuming processes of meaning reconstruction by these infomediaries temporarily hampered but finally facilitated the broader material diffusion of codes of conduct within the industry. These findings detail existing conceptualizations of code diffusion as they demonstrate how infomediaries-through creation, use, and reconstruction of explanatory accounts as well as frames of reference-participate in defining the relevance and meaning of CSR practices. I move beyond prior empirical work as I explicitly assess not only processes of meaning construction evolving around a CSR practice but also how these processes over time coincide with quantitative patterns of its material diffusion. Implications of my findings for existing research on the diffusion of codes of conduct specifically and CSR practices in general as well as for conceptualizations of diffusion from institutional theory are discussed.
\end{abstract}

Keywords Corporate code of ethics - Code of conduct · Diffusion · Discourse · Institutional theory · Infomediaries

F. Scheiber $(\bowtie)$

University of Mannheim, L9, 1-2, 68161 Mannheim, Germany

e-mail: scheiber@ifm.uni-mannheim.de; f.scheiber@gmx.de

\section{Introduction}

Systems of private self-regulation deemed at providing solutions for problems traditionally solved by states or governments have become a dominant organizational form in capitalist societies (Bartley 2007; Kaptein 2004; Kaptein and Wempe 2002). Especially so-called codes of conduct have diffused extremely rapidly throughout the past years, across both various industries and nation states (O'Rourke, 2003). As Kaptein (2004) finds, more than $50 \%$ of the two hundred largest companies in the world have a code of conduct. A growing body of research has started to assess the emergence (Bartley 2007), prevalence (Weaver et al. 1999), content (Kaptein 2004), effectiveness (Kaptein and Schwartz 2007), and diffusion (Wetterberg 2007; Bondy et al. 2004) of codes of conduct. Especially the latter aspect—diffusion-has gained increasing attention within the last years, not least spurred by the argument that the acceptance of codes of conduct and other CSR practices among organizations can hardly be determined solely on the basis of measurable economic outcomes (Margolis and Walsh 2003).

Recent work on the diffusion of codes of conduct specifically and CSR practices generally has thereby sought to explain the cultural processes by which these organizational practices come to be perceived as valuable and desirable by potential adopters (Chua and Rahman 2011). Conceptual work in this area has thereby improved our understanding of how so-called "infomediaries"-i.e., important mediators and brokers of information within an industry like business/news media, trade journals, or professional groups-participate in such cultural processes by reconstructing the meaning and relevance of CSR (Deephouse and Heugens 2009; Gond and Palazzo 2008) and empirical assessments have identified significant changes 
in the way infomediaries like business media have contributed to interpret CSR within the past decade (Grafström and Windell 2011). Nevertheless, in view of the few existing studies in this area, at least one pivotal question remains unanswered: Do changes in the way infomediaries construct the meaning of CSR practices interrelate with decisions by organizations to adopt these practices? The paper at hand intends to contribute to answering this question.

In order to do so, I outline a theoretical framework borrowing existing arguments on interrelations between meaning construction and diffusion from institutional theory (Meyer and Rowan 1977; Strang and Meyer 1993). In line with prior conceptual work (Deephouse and Heugens 2009), this framework suggests that discourses produced by infomediaries like trade journals or professional groups play a key role in processes of practice diffusion as they both reflect and shape the understanding of the worth of organizational practices among potential adopters (Alvarez et al. 2005). From a diffusion theoretical view, it is thereby argued that changes in the way infomediaries construct rationales for practice adoption and connect discussions on codes of conduct to other surrounding discourses should represent an important explanatory factor for temporal heterogeneity in patterns of their material diffusion (Strang and Soule 1998).

In order to examine my theoretical arguments empirically, I use a longitudinal case study design and analyze the diffusion of codes of conduct in the German textile and apparel industry between 1997 and 2010. The textile and apparel industry represents a specifically viable industry for studying code diffusion, because it was one of the first industries for which labor rights in globally dispersed supply chains became relevant and potentially shaped similar later developments in other industries (Bartley 2007). This industry thus allows us to study diffusion of codes of conduct across a notably long period of time and might hence hold insights that can yet not be observed in other industries. The German context thereby represents a prototypical case of code diffusion. Because of the existence of brand name firms like Adidas or Puma, upcoming discussions on labor rights violations in the US context were taken up comparably early within this industry and the first codes were already created at the end of the 1990s (Wick 2005). Nevertheless, it took almost 10 years until codes started to diffuse on a larger scale. Choosing the diffusion of codes of conduct in the German textile and apparel industry as a case thus allows me to study code diffusion across a comparably long period of time and to study phases of emergence as well as both stagnant and rapid diffusion in one case study.

My results show that the broader material diffusion of the most prominent code of conduct within this industry- the one provided by the BSCI (Business Social Compliance Initiative)-was preceded by a time-consuming process of discursive meaning (re)construction spurred by important infomediaries (a trade journal and a trade association) that both helped to obscure the initial rationales for practice creation and to construct new justifications for adoption as well as linkages to other prominent discourses. I find indications that this process of discursive "dress up" was fostered by powerful early adopters within the industry. Despite idiosyncrasies of the context this study is located in, the results of this study contribute to generating a better understanding for the spread of codes of conduct and CSR practices we observe today, as they demonstrate how meaning reconstruction by infomediaries like business media or professional groups can both hamper and facilitate their material diffusion.

\section{Theoretical Background}

Research from an institutional theory perspective (Powell and DiMaggio 1991) suggests that understanding the diffusion of organizational practices requires an assessment of the cultural processes through which arguments for their adoption are created, (re)constructed, and accepted in organizations' relevant environments (Meyer and Rowan 1977; Strang and Meyer 1993). In this view, the decision of an organization to adopt or reject an organizational practice will not only depend on a predetermined, universal technical fit between practice characteristics and organizational characteristics but also on whether the practice accords with culturally established understandings of appropriateness and rationality that exist in the social context the organization is bound to (Strang and Soule 1998)—i.e., is perceived as legitimate (Suchman 1995). Before an organizational practice can diffuse, it has to make sense for potential adopters within a social context (Green et al. 2009) and sense is often "given" to organizational practices by culturally legitimate others or "infomediaries" such as business/news media, trade journals, or professional groups - and transmitted via broadcasting channels of communication such as press articles, reports, books, or websites (Phillips et al. 2004). In this view, it has been argued that managers actively consume the so-created knowledge "by selecting and acquiring it on the basis of particular needs and preferences in order to translate it into action" (Alvarez et al. 2005, p. 129, 130). Inspired by these arguments from institutional theory, proponents of management fashion theory have conceptualized the diffusion of management practices as driven by a market for discourses promoting management knowledge in which media as infomediaries possess a crucial supply side role (Abrahamson and Fairchild 1999; Abrahamson 1996). 
Especially with respect to CSR practices, it has been argued that their acceptance among organizations can hardly be determined by their measurable economic outcomes. Rather, these practices are to a high degree open for interpretation (Grafström and Windell 2011) and the organizational outcomes they produce are at least disputable (Margolis and Walsh 2003). Therefore, it has been argued that the "diffusion success" as well as temporal heterogeneity in diffusion (Strang and Tuma 1993) of codes of conduct specifically and CSR practices in general will highly depend on how these practices become infused with meaning "beyond the technical requirements of the task at hand" (Selznick, 1957, p. 17) through the work of infomediaries such as business media or professional groups (Gond and Palazzo 2008; Deephouse and Heugens 2009).

The basic theoretical arguments on meaning construction and diffusion from institutional theory just outlined have become building blocks of nowadays classical conceptual models of practice diffusion [see, for example, Tolbert and Zucker (1996), Czarniawska and Joerges (1996), or more recently Green (2004)], and the role of infomediaries has been assessed empirically with respect to the diffusion of organizational practices such as corporate takeovers (Hirsch 1986), downsizing (Lamertz and Baum 1998), quality circles (Abrahamson and Fairchild 1999), knowledge management (Scarbrough et al. 2005), or total quality management (Green et al. 2009). Nevertheless, only few works exist, which have applied such established conceptual arguments to the diffusion of codes of conduct specifically or CSR practices generally. In fact, as Grafström and Windell (2011, p. 221) note, "given the important role that business media play in corporate life, scarce attention has been paid to the role of media in the construction and popularization of corporate social responsibility."

The few recent studies doing so are either conceptual in nature (Chua and Rahman 2011; Deephouse and Heugens 2009; Gond and Palazzo 2008) or concentrate on assessing changes in the way infomediaries report on CSR practices without aiming at also conceptualizing and measuring potential consequences of such cultural processes in terms of organizations' adoption behavior (Grafström and Windell 2011). In fact, this tendency to concentrate on analyzing discourses without thoroughly assessing material consequences in terms of adoption behavior is not confined to research on the diffusion of CSR practices, but has been described as a limiting factor of much diffusion research from an institutional theory perspective within the past years (Zilber 2008; Mazza and Alvarez 2000). In order to contribute to closing these gaps, I will combine existing theoretical arguments from institutional theory in order to derive empirically testable propositions on how reporting by infomediaries on codes of conduct within an industry should interrelate with organization's adoption behavior.

\section{Infomediaries and Material Practice Diffusion}

In line with existing research, I will define "infomediaries" as the group of organizations which transmit and refract information for an audience within an industry or field (Fombrun and Van Riel 1997)—like business/news media, trade journals, professional groups, analysts, or rating agencies. Infomediaries share at least two characteristics that make them an interesting object of investigation for diffusion research: First, it has been argued that infomediaries continuously "seek to maintain or improve their fit with the expectations held by other actors in their organizational field in order to improve their chances at survival and effectiveness" (Deephouse and Heugens 2009, p. 542). Consequently, reporting by infomediaries has to be in line with central norms and beliefs of the audience within the industry or larger context they are bound to, because deviating from consensual positions within the respective context would mean to deviate from values held by their core constituents (Vaara and Tienari 2009; Bauer et al. 2002). Content produced by infomediaries can thus be seen as containing "negotiated knowledge" (Kjær and Langer 2005 , p. 228) since contents result from an active engagement with a relevant audience. Second, infomediaries have been characterized as being more than transmitters or brokers of information (Deephouse and Heugens 2009). Rather, they have been described as political actors "doing the cognitive "groundwork" on which actors and organizations within an industry-consciously or unconsciously-frequently base their decisions (ibid., p. 546) (Alvarez et al. 2005).

In sum, infomediaries have been described as important "carriers" (Sahlin and Wedlin 2008) of management knowledge that may have the capacity to "block" or "facilitate" diffusion of organizational practices at their "strategic checkpoint" (Hirsch 1972, p. 649). By this means, infomediaries might influence adoption decisions of organizations and thus the diffusion of organizational practices in a number of ways. One basic proposition that has been derived from an agenda-setting perspective (McCombs and Shaw 1972) thereby suggests that the mere intensity of reporting on a certain issue or problem and practices that potentially help to deal with this issue might perpetuate practice adoption within/among firms (Carroll and McCombs 2003; Deephouse and Heugens 2009). In fact, as for example Burns and Wholey (1993) find, high levels of media coverage supported the diffusion of the matrix form in US hospitals in the 1960s and 1970s.

Furthermore, it has been argued that infomediaries might influence diffusion through the way they interpret 
and frame organizational practices-irrespective of reporting intensity (Hirsch 1986; Strang 1997; Mazza and Alvarez 2000). Existing research has thereby identified two central aspects of meaning construction that might affect adoption decisions by consumers of discourses produced by infomediaries surrounding the diffusion of an organizational practice: (1) explanatory accounts and (2) frames of reference. Especially this latter influence trajectory of infomediary reporting represents my core interest in this paper.

\section{Explanatory Accounts}

Explanatory accounts (Zucker 1977; Lamertz and Baum 1998)_often also termed "vocabularies of motive" (Mills 1940, p. 906)—are arguments which establish linkages between a focal practice and previously unaffected organizations through leveraging different "rationalities for adoption" (Etzion and Ferraro 2010, p. 1093). Especially in situations in which actors (in this case infomediary spokespersons) deviate from institutionalized norms, they provide accounts in order to justify their behavior, whereas only "a limited number of subject positions are understood as meaningful, legitimate and powerful" (Hardy et al. 2005 , p. 65) in given periods of time. Consequently, accounts point to the "taken for granted knowledge" that is available within the given context and simultaneously they refer to those actions which are deemed to be incompatible with the prevailing beliefs about appropriateness and rationality (Green 2004). Two aspects of explanatory accounts justifying adoption of an organizational practice provided by infomediaries might thus contribute to explaining patterns of material practice diffusion:

First, the content of explanatory accounts articulated by infomediaries might influence diffusion patterns. The creation of new or modified explanatory accounts supporting a practice brought forward by important infomediaries can significantly alter mechanisms of material practice diffusion because they might resonate with the needs of classes of organizations within an industry which beforehand did not deem adoption appropriate (Green 2004). In fact, as Lamertz and Baum (1998) demonstrate, the creation and modification of explanatory accounts for organizational downsizing in Canada between 1988 and 1994 led to an increasing acceptance and institutionalization of this once contentious practice. Mazza and Alvarez (2000, p. 582) find that popular media in Italy have contributed to the legitimation of Human Resource Management practices by generating ideological, non-technical explanations on how previously uninterested organizations might profit from adoption. Conferred to the diffusion of codes of conduct, this theoretical argument would thus suggest the following:
P1 The greater the share of explanatory accounts concerning codes of conduct brought forward by infomediaries that resonate with the needs of a specific group of organizations (e.g., small, non-brand companies), the more organizations from this group will subsequently adopt the practice.

Second, it has been argued that the relative frequency of explanatory accounts supporting a practice brought forward in (infomediary) discourses indicates how far the respective practice is perceived to be in need for a justification and can thus be seen as a proxy for the degree of cognitive institutionalization - or "taken for grantedness"-it enjoys within the given context (Lamertz and Baum 1998; Green 2004; Meyer 2004). As Zucker (1977, p. 726) notes, for "highly institutionalized acts, it is sufficient for one person simply to tell another that this is how things are done." From an institutional theory perspective, it has been argued that (cognitive) institutionalization is one central explanatory factor influencing practice diffusion: As a practice increasingly becomes part of institutionalized-and thus reciprocal and typified (Berger and Luckmann 1966)expectations concerning appropriate organizational behavior within a field, more and more organizations will adopt the practice in order to avoid social or economic sanctions-irrespective of the technical fit between the practice and adopter (DiMaggio and Powell 1983; Meyer and Rowan 1977; Deephouse and Suchman 2008). I thus propose the following:

P2 The greater the number of texts brought forward by infomediaries that comprise no explanatory account for the adoption of codes of conduct compared to the number of texts that comprise any kind of explanatory account, the more organizations within the industry will subsequently adopt the practice.

\section{Frames of Reference}

Besides explanatory accounts, existing research on meaning construction and diffusion points to the importance of "interdiscursivity" (Phillips et al. 2004, p. 644) — the way discussions evolving around a focal practice are connected to other surrounding discourses. Whether through analogies (Etzion and Ferraro 2010), comparisons (Creed et al. 2002), or direct references to other practices (Abrahamson and Fairchild 1999), it has been argued that the way producers of discourses draw on other (more or less prominent) discourses might heavily influence perceptions among discourse consumers (Fairclough 1992). Prior empirical work by Rao (1998) shows how proponents of consumer watchdog organizations skillfully drew on previously unconnected discourses (e.g., discussions in the retailing profession) in order to establish this new 
organizational form. In a recent study, Etzion and Ferraro (2010) found that analogies connecting the global reporting initiative (GRI) to established discourses on corporate financial reporting helped to legitimize this practice at its emergence. Abrahamson and Fairchild (1999, p. 730) observed that in the course of the diffusion of quality circles, authors of media texts started to employ "broadening tactics," thereby embedding the focal practice into a larger toolkit of practices. In line with prior theorizing, I thus propose the following:

P3 A positive relationship exists between the extent to which infomediaries connect reports on codes of conduct to other, well-established as well as prominent discourses (frames of reference) and the subsequent adoption of this practice by organizations within the industry.

In the remainder, I will employ the theoretical framework that has been outlined in the previous sections in order to assess the diffusion of codes of conduct in the German textile and apparel industry. The theoretical arguments and initial propositions just developed thereby serve as a toolkit that shall help to gain a deeper understanding for the relationship between meaning construction processes by infomediaries and the material diffusion of codes of conduct in this industry. The aim of my empirical assessment will thereby be twofold: On the one hand, I intend to test the above-formulated propositions that have been derived from existing theoretical arguments. On the other hand, I aim to develop finer-grained theoretical arguments concerning interrelations between infomediary reporting and the diffusion of codes of conduct than the ones just presented by understanding observable patterns with respect to the specific content of explanatory accounts and frames of reference. The openness of this theoretical framework for context- or practice-specific variations in the content of infomediary coverage interrelating with practice diffusion shall thus allow for an empirically driven expansion and detailing of existing theoretical arguments. I thereby extend prior research with a similar focus (Grafström and Windell 2011) as I not only assess processes of meaning construction on the discursive level but also their consequences in terms of material practice diffusion.

\section{Research Methods}

In order to assess the above-outlined theoretical arguments on the relationship between code diffusion and processes of meaning (re)construction empirically, I use a case study approach (Eisenhardt 1989). This approach has been proven suitable for assessing research questions that imply a combination of multiple data sources and complex diachronic interdependencies on different levels of analysis (Hartley 2009) as well as a mix of different methods (Yin 1994). My case study on the dissemination of codes of conduct in the German textile and apparel industry and its surrounding meaning construction processes is based on a historical case analysis, a quantitative assessment of adopter's characteristics, and an analysis of texts produced by infomediaries. For the historical case analysis, I use multiple data sources such as topic-related articles from the daily press and academia, political disclosures on the EU and (German) national level, WTO reports, publications by NGOs such as the clean clothes campaign (CCC), and time authentic archival material from different company and NGO websites from the mid 1990s to 2010. Archives from the website of the German division of the CCC containing more than 50 single documents (such as newsletters and press releases) are thereby used in order to identify all German companies that became targets of NGO campaigning activities between 1997 and 2010 (see Table 8 in Appendix 4).

\section{Material Diffusion of Codes of Conduct}

In order to approach the material diffusion of codes of conduct, I decided to concentrate on assessing diffusion patterns of one standardized code of conduct-the one provided by the business social compliance initiative (BSCI) - for three reasons: First, I wanted to make sure that the adoption incidents I study are comparable. It has been shown that interpretations of companies adopting individual code of conduct often vary dramatically (O'Rourke 2003). While some firms claim that they are adopters after having published a simple document describing abstract goals, others only claim to be adopters after having established whole departments that are responsible for monitoring target achievement. In contrast, the adoption of a standardized code implies certain fixed rules [e.g., an orientation toward international labour organization (ILO) norms], which make adoption incidents more comparable. Second, in terms of ex post data gathering, it would be impossible to trace back the publication of individual codes of conduct for a whole industry. Third, as also standardized codes of conduct vary in their consequences for adopters, I chose to analyze the most prominent standard by far in order to make adoption instances comparable and concurrently to gain a proxy for the prominence of codes of conduct per se. The BSCI code has been adopted by more than 700 European and 287 German firms, whereas codes by the fair labor association (FLA 36 members worldwide) or the ethical trading initiative (ETI 50 members worldwide) significantly lag behind with 
respect to membership numbers (BSCI 2012; FLA 2011; ETI 2011). ${ }^{1}$

Material diffusion patterns of the BSCI code of conduct in the German textile and apparel industry are analyzed using basic statistical methods like $T$-tests and Chi squared tests in Stata 10 (Hamilton 2008). I thereby analyze whether central organizational characteristics (such as company size or a company's media visibility) of new adopters underwent significant changes over time. I built a unique dataset comprising all 287 German BSCI code adopters from its emergence in 2003 until 2010 with the year of adoption as well as central organizational characteristics such as company size, legal form, listing status, media visibility, and supply chain position (B2B vs. B2C). Data on adoption years of companies using the BSCI code of conduct between 2003 and 2007 were-on request-provided by the BSCI itself; adoption years from 2008 to 2010 were obtained by a yearly assessment of the members section of the BSCI website (www.bsci-intl.org).

Organizational characteristics of adopters were obtained by manually assessing various data sources such as the Amadeus, Hoppenstedt, and the German Dun and Bradstreet databases as well as company websites and Commercial Registries. I thereby generated four variables that are used in the analyses of BSCI adoption patterns:

- The size of adopting companies was measured using data on adopter's annual turnover for the year before they adopted the BSCI code of conduct.

- Data on adopter's media visibility were obtained by searching for company names in German press articles between 2003 and 2010 using the Lexis Nexis database which captures most German newspapers (like "Frankfurter Rundschau") as well as magazines (such as "Der Spiegel") [see Fiss and Zajac (2006) for a similar approach]. The visibility score for each company was calculated using the arithmetic mean of their visibility for the 2 years prior to their adoption of the BSCI code of conduct. By this means, I avoid media articles that might have been published because the company had adopted the BSCI code of conduct. Note that the gathering of visibility data described here has, although using the same database (Lexis Nexis), been performed independently from the gathering of trade journal texts described in the following sections.

- I manually assigned companies to the category $B 2 C$ (Business to Customer) or B2B (Business to Business) based on their SIC industry code as well as a thorough coding of company websites. Adopters that (1), according to their SIC classification, belong to the

\footnotetext{
${ }^{1}$ It should be noted here that the BSCI demands less strict standards compared to the FLA or ETI standard (Egels-Zandén and Wahlqvist 2007).
}

retail sector and thus face end-consumer contact, adopters (2) that provided the opportunity for direct end-customer purchases on their websites (e.g., through a web-shop), or adopters (3) that, according to their website, carry a brand for end customers were assigned to the category $\mathrm{B} 2 \mathrm{C}$. All other companies were assigned to the category $\mathrm{B} 2 \mathrm{~B}$ (resulting in a binary variable $B 2 C$ ).

- Based on a matching of adopters with brand name firm lists provided by four established German media (Schwarzbuch Markenfirmen, BrandZ100, YouGov, and TextilWirtschaft), firms were assigned to either carrying a strong brand (binary variable) or not.

The analysis of material diffusion patterns based on these four variables and adoption dates provides the basis for a thorough understanding of if and how processes of meaning (re)construction by infomediaries actually yielded measurable consequences for the material diffusion of codes of conduct.

\section{Meaning Reconstruction by Infomediaries}

In order to capture potential meaning (re)construction processes within the industry, the historical case analysis and the assessment of material diffusion patterns are further complemented by a systematic analysis of articles produced by two important infomediaries. My first data source is thereby articles from the most widely read trade journal by far within the German textile and apparel industry, the "TextilWirtschaft" (in the following: TW). TW weekly appears in print with a circulation of around 25.000 copies and is "the only journal for the complete German textile and apparel industry within the Germanspeaking region. [...] readers are the retail industry and the textile and apparel industry" [italics added]. TW is not an academic journal, but a trade journal with authors who are mostly professional journalists instead of researchers or members of firms within the industry. The second data source for textual analysis is annual reports published by the Foreign Trade Association of the German Retail Industry (AVE-Außenhandelsvereinigung des Deutschen Einzelhandels). Although formally representing the foreign trade interests of the whole German retail industry, this trade association focuses on the textile and apparel retail sector. This is also reflected in the configuration of the AVE executive committee, in which five of seven members represent the parts of the textile and apparel industry. ${ }^{2}$ Trade associations are said to play a similar infomediary role like trade journals as they present consensual industry positions to outside stakeholders while at the same time

\footnotetext{
${ }^{2}$ Source http://www.ave-koeln.de/praesidium/index.htm. Accessed 19 April 2011.
} 
functioning as arenas of intra-industry dialog (Greenwood et al. 2002). As trade associations' existence depends on the willingness of their respective industry to provide them with resources, their annual reports can be seen as central instruments to give account within the industry.

Interestingly, the trade journal (TW) and the trade association (AVE) are both highly infiltrated by institutions and actors which possess an exposed stance within the industry. The journal TW frankly communicates its partnership with the BTE (a trade association from the retail sector), and can thus be seen as influenced by actors from the (eminently visible) retail sector. The board of the AVE consists of seven members of whom five are delegates from highly visible firms within the industry, and has promoted the BSCI code of conduct since its emergence.

I analyze texts from TW and AVE annual reports by counting recurrent "explanatory accounts" (Lamertz and Baum 1998) brought forward in order to justify the firm's engagement with codes of conduct as well as frames of reference that were used when discussing the topic in order to capture central processes of meaning (re)construction during the diffusion process. The coding unit for explanatory accounts is the text segment, which is-in line with prior work-defined as a "statement that was meaningful and that expressed a basic yet complete idea" (Etzion and Ferraro 2010, p. 1095). For frames of reference, whole texts represent the coding unit as I was interested in the larger topic discussions evolving around codes of conduct became embedded in over time. Taken together, one text in the sample can thus comprise zero, one, or more explanatory accounts, while one text always comprises only one frame of reference. The selection of relevant texts and development of coding categories are described in the next sections.

\section{Selection of Articles and Time Period}

By generating a word list which was transferred into a search algorithm, all articles from the TW were identified, which contained single or combinations of "issue markers" (Donati 1992, p. 146)—such as "code of conduct" and its German translation "Verhaltenskodex" or "Business Social Compliance Initiative" - and were thus concerned with the topic of codes of conduct (for the list of issue markers, see Table 5 in Appendix 1). I searched for articles from TW containing any of the issue markers using the online database Lexis Nexis which captures all articles from the TW for the time period I am interested in. For each identified TW article, I then manually checked whether it in fact dealt with the issue. Articles which did not deal with the topic were sorted out manually. The resulting sample of TW texts contains 158 articles, differing in length from a few lines to several pages. The parts out of the AVE annual reports were selected manually. Parts of each annual report from 1997 to 2010-except for 1999 where no report was published and 2010 where no report was available during data gathering-dealing with the topic were included into the dataset.

The earliest year of the period under study was chosen firstly by considering one central event with respect to code development within the German textile and apparel industry and secondly on the basis of the availability of data. The founding of the German division of the CCC ("Kampagne für Saubere Kleidung") in 1996 can be seen as a central event which triggered the public debate concerning working conditions within the supply chains of German textile and apparel companies. In the same year, several large actors within the industry-like, for example, Otto GmbH and KarstadtQuelle-decided to publish their first codes of conduct. The above-described datasets were available in parallel from 1997 onward, which meant that setting the starting point in 1997 was a compromise between data availability and external events. The period under study ends with the year 2010. The sample for the study thus consists of 158 articles from TW and the parts of 12 AVE annual reports between 1997 and 2009, which were chosen based on the procedure just described.

\section{Textual Analysis}

The sample of 170 texts was analyzed in three stages in order to identify and code "explanatory accounts" (Lamertz and Baum 1998) as well as recurrent frames of reference (Fairclough 1992; Benford and Snow 2000). Within a first step, the data were open coded (Bauer and Gaskell 2000) using MAX.QDA in order to identify central "explanatory accounts" for the adoption or continuation of voluntary practices dealing with the problem of poor labor conditions. The first stage of analysis resulted in a total number of 156 explanatory accounts that I was able to identify.

In a second step, by iterating between the whole set of explanatory accounts and theory, the accounts were subdivided into three categories. One class of accounts could be identified which refer to external pressures as the cause for the adoption of codes of conduct. These justifications were subsumed under the category "pressure." The category was additionally subdivided into the categories "public" and "regulation." The former subsumes justifications which point to public pressure exerted by NGOs, interest groups, or the general public. The latter captures accounts which formulate imminent or existing laws, edicts, or trade sanctions (e.g., by the WTO, EU commission) as a justification for the engagement with codes of conduct. (2) A second category was identified consisting of those justifications which refer to moral/ethical reasoning 
or to deeply held beliefs that this was "the right thing to do" instead of any kind of external pressure or other argument in order to constitute the engagement with codes of conduct. These accounts were subsumed under the category "normative." (3) The third category ("business case") subsumes those kinds of actors' statements which justify dealing with or implementing practices of labor standards by reverting to potential economic consequences. These arguments often pointed to the potential of codes of conduct as a marketing instrument, as a means to monitor suppliers more efficiently or as a strategic investment because of the increasing importance of sustainability issues in society. Accounts within this category thus represent typical resource-based arguments for CSR practice adoption (Bansal 2005). Examples for each coding category can be found in Table 1 .

In a third step, by moving from text segments as the units of analysis to whole texts, all 170 texts in the dataset were coded for two further aspects. First, those texts were identified which were explicitly concerned with the adoption or maintenance of a code of conduct without delivering any justification. Put differently, every whole text/article was coded for containing either any kind of explanatory account (as described above) or no account at all (for example, illustrating the coding procedure for this category, see Table 6 in Appendix 2 and see Table 7 in Appendix 3).

Additionally, on the level of whole texts, each of the texts within the dataset was classified according to the larger discourse (frame of reference) it was connected toreferred from the text's headline as well as introductory and concluding sentences. Hereby, six frames of reference were identified [(1) codes of conduct as the focal topic, (2) situation of the industry, (3) natural and social environment, (4) CSR/Sustainability concepts in general, (5) tariffs/WTO, and (6) ethical fashion]. For articles coded as dealing with codes of conduct as the focal topic (1), no other frame of reference authors tried to connect their articles to could be identified. In line with my theoretical framework, this coding enables us to understand whether the frame of reference the topic of codes of conduct was embedded in changed over time (see Table 2 for more detailed descriptions of the categories).

\section{Stages of Overall Data Analysis}

Taken together, the methods and data just outlined build the basis for the detailed analysis of the diffusion of codes of conduct in the German textile and apparel industry between 1997 and 2010 which is presented in the following sections. The overall analysis and interpretation of data and results were thereby conducted in four stages: In the first stage, I constructed the above-described event history database in order to understand the historical sequence of
Table 1 Explanatory accounts

\begin{tabular}{ll}
\hline Explanatory account & Example* \\
\hline Public & The pressure exerted on brands towards \\
'clean production' grows constantly. \\
That is why it is increasingly \\
important for vendors to prepare for \\
attacks by implementing codes of \\
conduct and controlling production \\
(TW June 13, 2002) \\
Industry and trade can no longer elude \\
from demands of relief organizations \\
to take responsibility for the local \\
conditions (TW December 30, 2004) \\
Textile and apparel retailers have to \\
reckon attacks by social or churchly \\
groups, because they or their suppliers \\
employ children or forced laborers. A \\
recent example was an accusation by \\
the 'CCC' targeted at Tchibo, stating \\
that the company would 'Culpably \\
disregard and ruthlessly violate people \\
and worker's rights' at their suppliers. \\
That is why the BTE recommends- \\
especially for larger companies- to \\
join the BSC Initiative that was \\
launched in 2003 by the FTA. (TW \\
March 17, 2005) \\
Because
\end{tabular}

Regulative Because of numerous activities on the European level-e.g., hearings of the [European] commission-as well as an according passage in the coalition agreement of the [German] federal government, the importing business has identified the necessity to achieve a consensus concerning the activities of the private sector (AVE 1999, p. 1)

Trade sanctions would be no viable instrument in order to enforce social minimum standards. voluntary actions, like the code of conduct recently agreed upon by the AVE, would be better, says Reinhard Koep (TW December 9, 1999)

Normative

With an own monitoring of the AVE code of conduct, the German importing business intends to face the responsibility for the compliance with human rights and social standards in supplier countries (AVE 2001, p. 3)

Together with companies and associations from other European countries, the AVE supports a broad initiative that aims at an improvement of the social conditions in the supply chain and for this reason gives proof of companies' ethically responsible actions (AVE 2003, p. 2)

As a large company, we are aware that we cary a big responsibility. Our customers know that we have a code of conduct and that we are very active in this regard (TW October 6, 2005) 
Table 1 continued

\begin{tabular}{|c|c|}
\hline Explanatory account & Example $^{*}$ \\
\hline \multirow[t]{3}{*}{ Business case } & $\begin{array}{l}\text { The adherence to social standards could } \\
\text { contribute to an increase in } \\
\text { productivity and of supplier reliability } \\
\text { Bad working conditions not } \\
\text { uncommonly lead to worse work } \\
\text { quality, as it says in a brochure of the } \\
\text { round table for codes of conduct (TW } \\
\text { September 2, 2004) }\end{array}$ \\
\hline & $\begin{array}{l}\text { Sustainable trade is already suitable for } \\
\text { the mass. The number of labels with } \\
\text { ecological and ethical orientation } \\
\text { grows constantly. This shows that the } \\
\text { demand for ethical fashion brands } \\
\text { grows which bet on fair production } \\
\text { conditions and ecological raw } \\
\text { materials (TW December 28, 2006) }\end{array}$ \\
\hline & $\begin{array}{l}\text { A better social performance of suppliers } \\
\text { is required under social aspects, but it } \\
\text { also contributes to enhancing the } \\
\text { competitive position (AVE 2002, } \\
\text { p. 21) }\end{array}$ \\
\hline
\end{tabular}

* All direct quotes from TW articles and AVE annual reports presented here have been translated from German to English by the author of this paper

Table 2 Frames of reference

\begin{tabular}{ll}
\hline Frame & Description \\
\hline Focal topic & $\begin{array}{c}\text { Codes of conduct, social standards, or poor working } \\
\text { conditions are the main focus of the article. } \\
\text { The article deals with the situation of the sector as a } \\
\text { whole or reports on single companies without an } \\
\text { explicit focus on the focal topic. }\end{array}$ \\
Industry & $\begin{array}{l}\text { The article deals with both social and ecological } \\
\text { issues as its main topic. }\end{array}$ \\
Eco/social & $\begin{array}{c}\text { The topic is discussed under the larger topic of } \\
\text { "corporate social responsibility," "corporate } \\
\text { citizenship," or "sustainability". }\end{array}$ \\
sustainability & $\begin{array}{c}\text { The main focus of the article is discussions around } \\
\text { tariffs or WTO rounds. }\end{array}$ \\
Tariffs & $\begin{array}{c}\text { The article reports on developments within the } \\
\text { realm of the ethical fashion "movement". }\end{array}$ \\
Ethical fashion &
\end{tabular}

important events as well as the role of important actor groups (such as NGOs, industry associations, and institutions like the WTO and EU government as well as important media) therein. After that, I decided on the above-described infomediaries as the source of my textual analysis and performed the selection of articles as well as the coding of texts.

During the coding procedure (second stage) in which I iterated between theory and data, I was also able to detail the above-described event history database based on additional information I found in the texts. Since besides understanding how the discourse on codes of conduct had evolved over time, one of my main interests was to gain a measure for its material diffusion, I started to evaluate different options for gathering adoption data. Because of the reasons described above (e.g., comparability), I decided-in the third stage - to analyze the diffusion of the BSCI code of conduct. The quantitative assessment of BSCI adoption patterns was thus performed after I had analyzed important historical events and texts under study, in order to prevent a biased interpretation of textual data caused by observations concerning adoption patterns made before.

In the fourth stage, I allocated historical events, observable changes in media discourses, and adoption patterns to a time bar and by this means constructed a narrative summary of my data sources. By iterating between theoretical arguments and this narrative summary, the depiction of the diffusion process presented in the following sections was created. In line with the theoretical framework, I thereby especially accounted for interdependencies between patterns of material diffusion (quantitative analysis of adopters) and processes of meaning (re)construction in articles from infomediaries (textual analysis). Based on central events, I split the whole time period into three phases: The first phase (1997-2002) ends before the establishment of the BSCI code of conduct and the second time period ends in 2006, the year prior to a phase of its rapid diffusion.

\section{Results: Codes of Conduct in the German Textile and Apparel Industry, 1997-2010}

In the early 1990s, several campaigns conducted by NGOs and consumer groups revealed that the treatment of workers within globally fragmented supply chains of western textile and apparel companies strongly violated principal beliefs concerning human rights held within western societies (Elliot and Freeman 2001). Harmful working conditions, child labor, and low wages are just a fraction of accusations companies were facing. Large, image-conscious US-based firms like Levi's, Wal-Mart, or Nike were among the first to adopt so-called codes of conduct in order to repair reputation in the eyes of their consumers and the wider public (Braun and Gearhart 2004; Elliot and Freeman 2001; Bartley 2007). Although with a certain time lag, similar campaigns also emerged in the German textile and apparel industry, especially led by the 1996-founded German division of the CCC (Hiss 2009; Wick 2005). Within the same time period, the topic additionally received increasing interest by the World Trade Organization (WTO) and the EU government (GTZ 2002). Thus, at least until the turn of the millennium, where it became clear that voluntary instead of binding solutions 
Table 3 T-tests and Chi squared tests of adopter's characteristics over time

\begin{tabular}{llllllll}
\hline Variable & $2003-2006$ & $2007-2008$ & $2009-2010$ & $2007-2010$ & $\begin{array}{l}2003-2006 \text { versus } \\
2007-2008\end{array}$ & $\begin{array}{l}2007-2008 \text { versus } \\
2009-2010\end{array}$ & $\begin{array}{l}2003-2006 \text { versus } \\
2007-2010\end{array}$ \\
\hline $\begin{array}{l}\text { Number of } \\
\text { adopters }\end{array}$ & 11 & 79 & 199 & 278 & $p$ values of two-sample mean value $T$-tests & $<0.01$ \\
$\begin{array}{c}\text { Average adopter } \\
\text { size (T€) }\end{array}$ & $3,822,553$ & 321,488 & 54,025 & 102,547 & $<0.01$ & $<0.11$ & $<0.01$ \\
$\begin{array}{l}\text { Average adopter } \\
\text { visibility }\end{array}$ & 501 & 23 & 20 & 21 & $<0.01$ & $<0.87$ & $<0.01$ \\
$\begin{array}{l}\text { Share B2C } \\
\text { adopters }\end{array}$ & $100 \%$ & $22 \%$ & $23 \%$ & $22 \%$ & $<0.01$ & $<0.80$ \\
$\begin{array}{l}\text { Share brand name } \\
\text { adopters }\end{array}$ & $82 \%$ & $9 \%$ & $4 \%$ & $5 \%$ & $<0.01$ & $<0.11$ & $<0.01$ \\
\hline
\end{tabular}

would be favored on the WTO and EU level, companies had-besides NGO campaigns and protests-to anticipate upcoming binding standards (Greven and Scherrer 2005; Gatto 2011). From 1996 onward, a number of highly visible brand name firms and retailers within the industry, like C\&A (1996), Adidas (1996), the Otto Group (1997), or KarstadtQuelle (1999), started to react to these developments (either due to direct demands by NGOs or spillover effects (Jonsson et al. 2009)) by introducing first individual codes of conduct.

Within the US as well as the German textile and apparel industry, the early "campaigning" phase just described was subsequently followed by a "solutions phase" (Braun and Gearhart 2004, p. 183) in the course of which multiple variations of the overall concept "code of conduct" emerged. Besides company-specific codes, especially so-called multistakeholder initiatives introducing standardized codes of conduct emerged - like the FLA in the USA (1999), the ETI (1998), the Fair Wear Foundation (1999), and the social accountability initiative (SAI, SA8000 standard) (1998). Additionally, and most influential with respect to the German context, the BSCI was founded which introduced its own standardized code of conduct in 2003 (Wick 2005; Hiss 2009; Egels-Zandén and Wahlqvist 2007).

\section{Material Diffusion of the BSCI Code of Conduct}

Nevertheless, as the quantitative assessment of BSCI adoption patterns shows, the BSCI code went through a long phase of acutely slow diffusion after its emergencebetween 2003 and 2006, only 11 companies adopted the code. These adopters had an average size of 3.8 billion Euros in turnover and an average media visibility of 501 articles in German popular media during the 2 years prior to their adoption. All adopters in this first period were business to customer companies and the vast majority was brand name firms $(82 \%)$.
This picture changed dramatically between 2007 and 2010, where 278 companies decided for adoption. The results of the statistical analysis (see Table 3) thereby reveal significant differences between early and later adopters. New adopters for the years 2007-2010 had a significantly lower $(p<0.01)$ average size in terms of yearly revenues (102 million Euros) compared to adopters between 2003 and 2006 (3.8 billion Euros) and a significantly lower $(p<0.01)$ average visibility in the press of 21 articles in the 2 years prior to their adoption (compared to 501 articles for adopters between 2003 and 2006). Only $22 \%$ of these later adopters were business to customer companies (100\% in the prior period) and only $5 \%$ were brand name firms ( $82 \%$ in the prior period). Chi squared tests reveal that both of these differences are significant $(p<0.01)$.

In order to get a more precise picture of adoption patterns within this last time period, I additionally split the period into two sub-periods (2007-2008 and 2009-2010). Here, we observe that over time, especially the average size of new adopters reduced drastically (from 321 million (2007-2008) to 54 million (2009-2010) Euros in turnover). Nevertheless, the $T$ test on differences of average sizes is slightly insignificant on a $10 \%$ confidence level $(p<0.11)$. In terms of visibility and adopters that are business to customer firms, we rather see stability on a low level (around 20 press articles and $20 \%$ B2C adopters for both periods). With respect to the share of new adopters that were brand name firms, it becomes obvious that in the last period (2009-2010), only $4 \%$ of new adopters were brand name firms (compared to $9 \%$ between 2007 and 2008 and $100 \%$ between 2003 and 2006). Nevertheless, this decrease in brand name adopters between 2007/2008 and 2009/2010 is slightly insignificant ( $p<0.11)$.

The assessment of new adopter's characteristics over time thus seems puzzling at first sight. In light of the fact that throughout the whole time period under study 


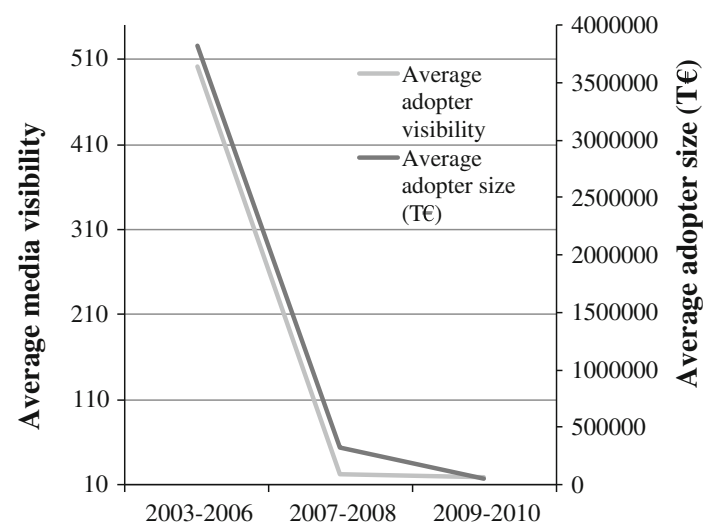

Fig. 1 New adopters' average visibility and size across time periods

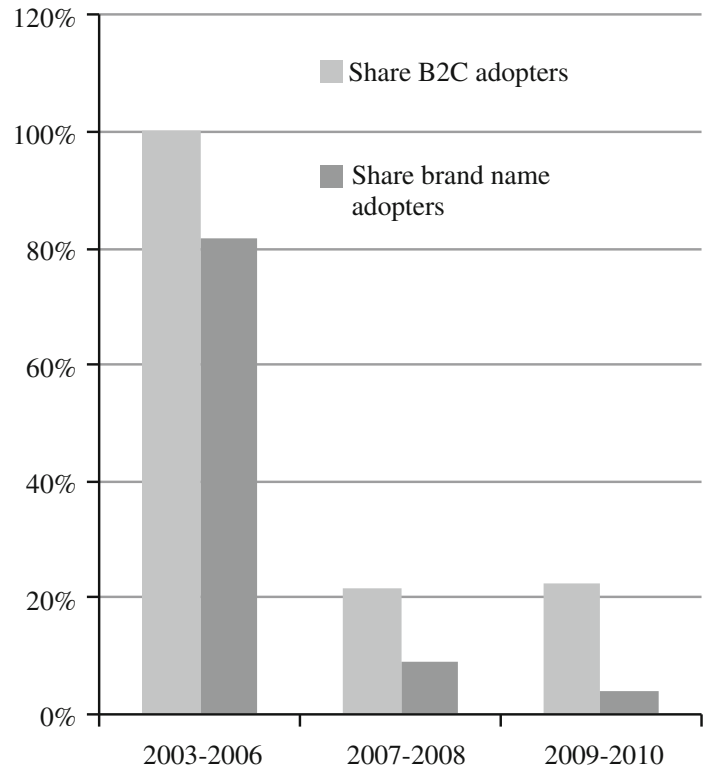

Fig. 2 B2C and brand name adopters across time periods

(1997-2010), NGO campaigns exclusively targeted large brand name firms within the industry (see Table 8 in Appendix 4), the question arises as to why so many small companies with a low media visibility that are mostly nonbusiness to customer and non-brand name companies decided to adopt the BSCI codex in recent years (see Figs. 1, 2 for an overview). In other words, why did the code of conduct exist for years without considerable adoption by these firms and suddenly start to diffuse among these organizations? $?^{3}$ A potential answer to this question arises in view of the results of the textual analysis.

\footnotetext{
3 An alternative answer to this question might be that the negative media attention produced by the scandals at the end of the 1990s led to negative legitimacy spillovers within the industry which then provoked adoption by "innocent" firms. Nevertheless, prior research has shown that negative legitimacy spillovers are mostly immediate
}

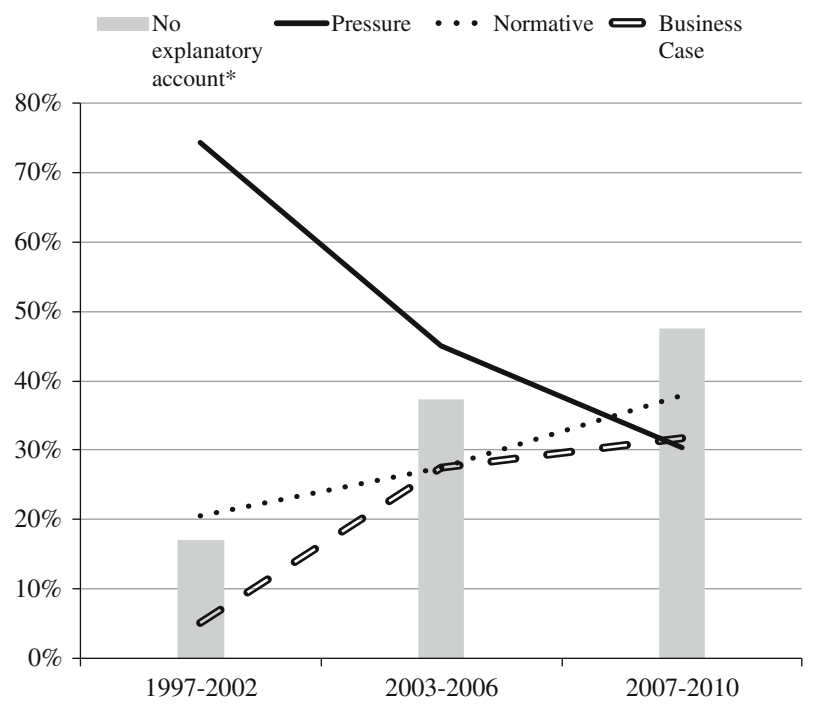

Fig. 3 Results of explanatory account analysis (asterisk) of number of whole texts that contain no explanatory account relative to number of texts that contain any kind of account

\section{Explanatory Accounts}

Throughout the whole time period under study (1997-2010), we observe that both content and frequency of explanatory accounts brought forward by infomediaries under study changed quite dramatically (see Fig. 3). Over time, explanatory accounts referring to external pressures as a justification for dealing with the topic were increasingly replaced by explanatory accounts pointing to the moral responsibility of the industry and accounts which rationalized codes of conduct by referring to their favorable economic consequences. More precisely, while between 1997 and 2002, 29 (74 \%) out of 39 overall explanatory accounts justify the engagement with codes of conduct as driven by external pressures, the importance of these accounts decreases to $45 \%$ between 2003 and 2006 and finally to $30 \%$ of all accounts between 2007 and 2010 . Instead, normative justifications (21\% 1997-2002, $38 \%$ 2007-2010) as well as arguments constructing a business case (5\% 1997-2002, $32 \%$ 2007-2010) strongly gain importance. The following examples from the text material illustrate this development.

\section{External Pressures (Public)}

Child labor in preliminary production stages has not sparked the interest of small and medium sized textile

\section{Footnote 3 continued}

reactions by an audience (Jonsson et al. 2009). Thus, this argument does not hold in view of the considerable time lag between intense scandal-based reporting and massive adoption by small, non-brand firms ( $>5$ years). 
retailers yet. Since a couple of months, Hennes \& Mauritz, C\&A and Otto experience how problematic it can be to neglect this topic. Although conditions of purchasing of all three firms prohibit child labor, they have become targets of the "Clean Clothes Campaign" that was initiated by a churchly and social coalition. Allegedly, H\&M has already faced calls for boycotts in Sweden. That means: Also the small and medium sized textile and apparel retail sector should duly_within its means-start to deal with the topic in order to be able to answer customer requests effectively and to avoid unnecessary trouble (TW; Feb 5, 1998).

External Pressures (Regulative)

Trade sanctions would be no appropriate instrument to assure the compliance with social minimum standards. A better approach were voluntary activities by the importers like the 'Code of Conduct' recently terminated by the AVE (TW; Dec 9, 1999).

Normative

With an own monitoring of the AVE Code of Conduct, the German importing business intends to face the responsibility for the compliance with human rights and social standards in supplier countries (AVE; 2001, p. 23).

Social and environmental standards become an increasingly important topic in procurement [...] Textile and apparel retailers can actively contribute to protecting environment, nature and the development of civil society and future perspectives in poor countries" (TW; May 4, 2006).

Business Case

The adherence to social standards could contribute to an increase in productivity and of supplier reliability. Bad working conditions not uncommonly lead to worse work quality, as it says in a brochure of the round table for codes of conduct (TW; Sep 2, 2004). Monitoring-one system for all? One code of conduct, the same guidelines and a consistent evaluation scheme lead to synergy effects for companies with respect to overlapping supplier relationships. "If we observe a problem with one supplier, we are able to observe which companies have contracts with this supplier. We can then get all parties involved to sit down at a single table and to figure out how to proceed. All parties are comparably interested to find a

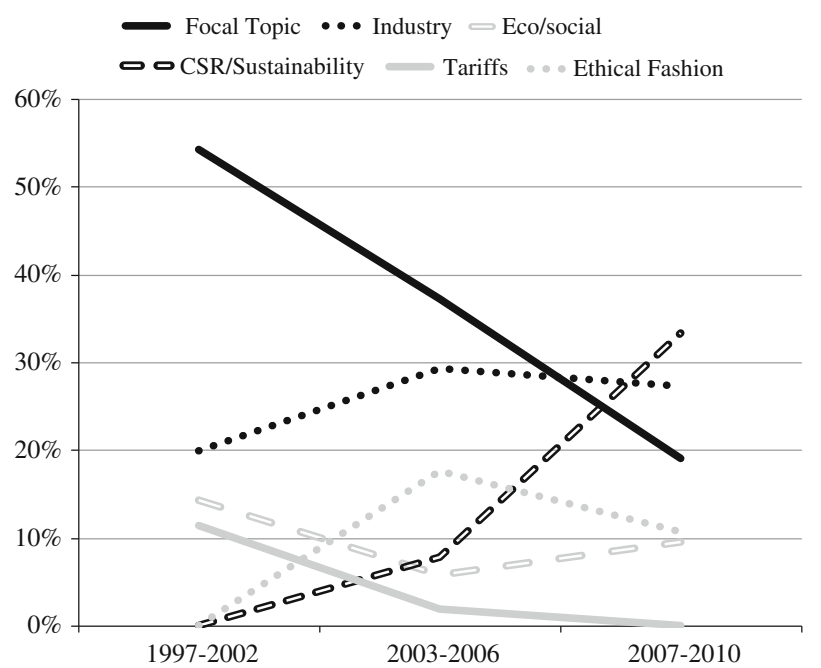

Fig. 4 Results of frames of reference analysis

solution because they are all in the same boat (TW;

Aug 17, 2006).

Additionally, on the basis of whole articles, we observe that over time, authors of industry media articles increasingly refuse to provide any kind of justification for why firms should start to deal with the topic. While in the period from 1997 to 2002, $83 \%$ of all texts I analyzed contained at least one explanatory account and thus at least one explicit reason for why companies should deal with the topic of codes of conduct, this number decreases to $63 \%$ between 2003 and 2006. Between 2007 and 2010, roughly every other (48\%) industry article now refuses to provide any kind of account for dealing with codes of conduct.

\section{Frames of Reference}

We also observe changes in the way articles dealing with codes of conduct are connected to other discourses within the industry (see Fig. 4). While in early periods, codes of conduct were mostly discussed as a relatively isolated phenomenon, more recent articles attempt to connect the topic to other relevant discourses such as the larger CSR discourse or more general industry reports. More precisely, between 1997 and 2002, articles dealing with codes of conduct mostly focused on the focal topic of codes of conduct (53\%). Between 2003 and 2006, the proportion of articles dealing with codes of conduct as a focal topic decreased to $37 \%$, while the topic is now rather embedded in more general industry reports $(29 \%)$ or other topics like ethical fashion (18\%). This development continued between 2007 and 2010: We observe that the topic of codes of conduct is still often embedded in general industry reports $(27 \%)$ and increasingly discussed by articles dealing with the topic of CSR and sustainability as the 
Table 4 Explanatory accounts and frames of reference

\begin{tabular}{|c|c|c|c|c|c|c|}
\hline & \multirow{2}{*}{\multicolumn{2}{|c|}{$\frac{1997-2002}{\text { Number }}$}} & \multicolumn{2}{|c|}{ 2003-2006 } & \multicolumn{2}{|c|}{ 2007-2010 } \\
\hline & & & Number & $\%$ & Number & $\%$ \\
\hline \multicolumn{7}{|c|}{ Explanatory accounts based on text segments (Proposition 1) } \\
\hline \multicolumn{7}{|l|}{ Pressure } \\
\hline Regulation & 10 & 34 & 3 & 13 & 0 & 0 \\
\hline Public & 19 & 66 & 20 & 87 & 20 & 100 \\
\hline $\begin{array}{l}\text { Sum } \\
\text { (Regulation }+ \text { Public) }\end{array}$ & 29 & 74 & 23 & 45 & 20 & 30 \\
\hline Normative & 8 & 21 & 14 & 27 & 25 & 38 \\
\hline Business case & 2 & 5 & 14 & 27 & 21 & 32 \\
\hline Sum & 39 & 100 & 51 & 100 & 66 & 100 \\
\hline \multicolumn{7}{|c|}{$\begin{array}{l}\text { Any explanatory account/no explanatory account based on whole texts } \\
\text { (Proposition 2) }\end{array}$} \\
\hline $\begin{array}{l}\text { Any explanatory } \\
\text { account }\end{array}$ & 29 & 83 & 32 & 63 & 44 & 52 \\
\hline No explanatory account & 6 & 17 & 19 & 37 & 40 & 48 \\
\hline Sum & 35 & 100 & 51 & 100 & 84 & 100 \\
\hline \multicolumn{7}{|c|}{ Frames of reference based on whole texts (Proposition 3) } \\
\hline Focal topic & 19 & 54 & 19 & 37 & 16 & 19 \\
\hline Industry & 7 & 20 & 15 & 29 & 23 & 27 \\
\hline Eco/social & 5 & 14 & 3 & 6 & 8 & 10 \\
\hline CSR/sustainability & 0 & 0 & 4 & 8 & 28 & 33 \\
\hline Tariffs & 4 & 11 & 1 & 2 & 0 & 0 \\
\hline Ethical fashion & 0 & 0 & 9 & 18 & 9 & 11 \\
\hline Sum & 35 & 100 & 51 & 100 & 84 & 100 \\
\hline
\end{tabular}

frame of reference (33\%), rather than exclusively focusing on the topic itself $(19 \%)$.

\section{Consolidation of Results}

Taken together, the three meaning reconstruction processes on a discursive level just described (for a summary, see Table 4) should have contributed to generating an understanding for codes of conduct among potential adopters that emphasizes the "fit" of this practice not only for large, brand name firms but also for smaller, less visible, and previously uninterested companies within the industry. Combined with the results of the quantitative assessment of BSCI adopters between 2003 and 2010, it is striking to see that - in line with the theoretically derived propositionsthe rapid material diffusion of this code of conduct in recent years among small and largely invisible firms only took off after infomediaries had started to attach new meanings to this practice, which resonate with the needs of this new class of adopters.

These observations can be interpreted in at least two slightly different ways: On the one hand, it could be argued that the industry as a whole increasingly discovers its true moral commitment, the potential economic value of implementing codes of conduct, and its interrelations with other upcoming topics such as CSR and sustainability. On the other hand, the observations can be interpreted in the light of specific characteristics of the infomediaries under study. The TW and the AVE are both highly infiltrated by institutions and actors which possess an exposed stance within the industry (see "Research Methods" section). It can thus be assumed that the infomediaries under study are directly (AVE) or indirectly (TW) to a large extent infiltrated by the interests of large and visible firms within the industry. These firms-as mentioned before-are in turn those actors that were the pioneers with respect to the implementation of codes of conduct (some of them participated in developing the BSCI codex and were the first adopters) and should have a strong interest in affecting further firms within the industry to adopt these practices for at least three reasons:

First, it can be assumed that it is beneficial for these important players within the industry to now try to impose their (sunk)costs for implementing codes of conduct on the rest of the industry (Martin 2002; Bartley 2007). Second, the existing practices that were developed or adopted by these players are in strong need for legitimation outside the industry (NGOs, government). With an increasing number of further actors employing these practices (e.g., the BSCI codex), the legitimacy of these practices will increase in the eyes of external observers. ${ }^{4}$ Third, the creation of rationalized accounts (business case) and the connection to prominent topics such as CSR may help to provide early adopters with more legitimate claims toward industry internal and external stakeholders (e.g., shareholders, corporate customers) when justifying the commitment of organizational resources to respective practices. Taking these arguments together, the second interpretation for the observable discursive shift rests on the assumption of incipient mechanisms of intra-industry pressure/persuasion. This would mean that visible actors within the industrywith a certain time delay-attempt to infiltrate processes of meaning (re)construction evolving around codes of conduct with new rationalizations or "theorizations" (Strang and Meyer 1993) that appeal to less visible firms within the industry (risk/reputation management arguments diverge for such an attempt).

Irrespective of this potential role of early adopters within the industry, the results just presented can be seen as a strong indicator for the validity of the basic theoretical proposition that infomediaries possess a prominent role when it comes to defining the meaning and worth of CSR

\footnotetext{
${ }^{4}$ It could also be argued that adopters have an interest in preventing further adoptions because of market differentiation. Nevertheless, this argument seems to be weaker, because nearly all large players have already adopted at this point in time, meaning that in their competitive subfield, a code of conduct has lost its potential value as a tool for market differentiation.
} 


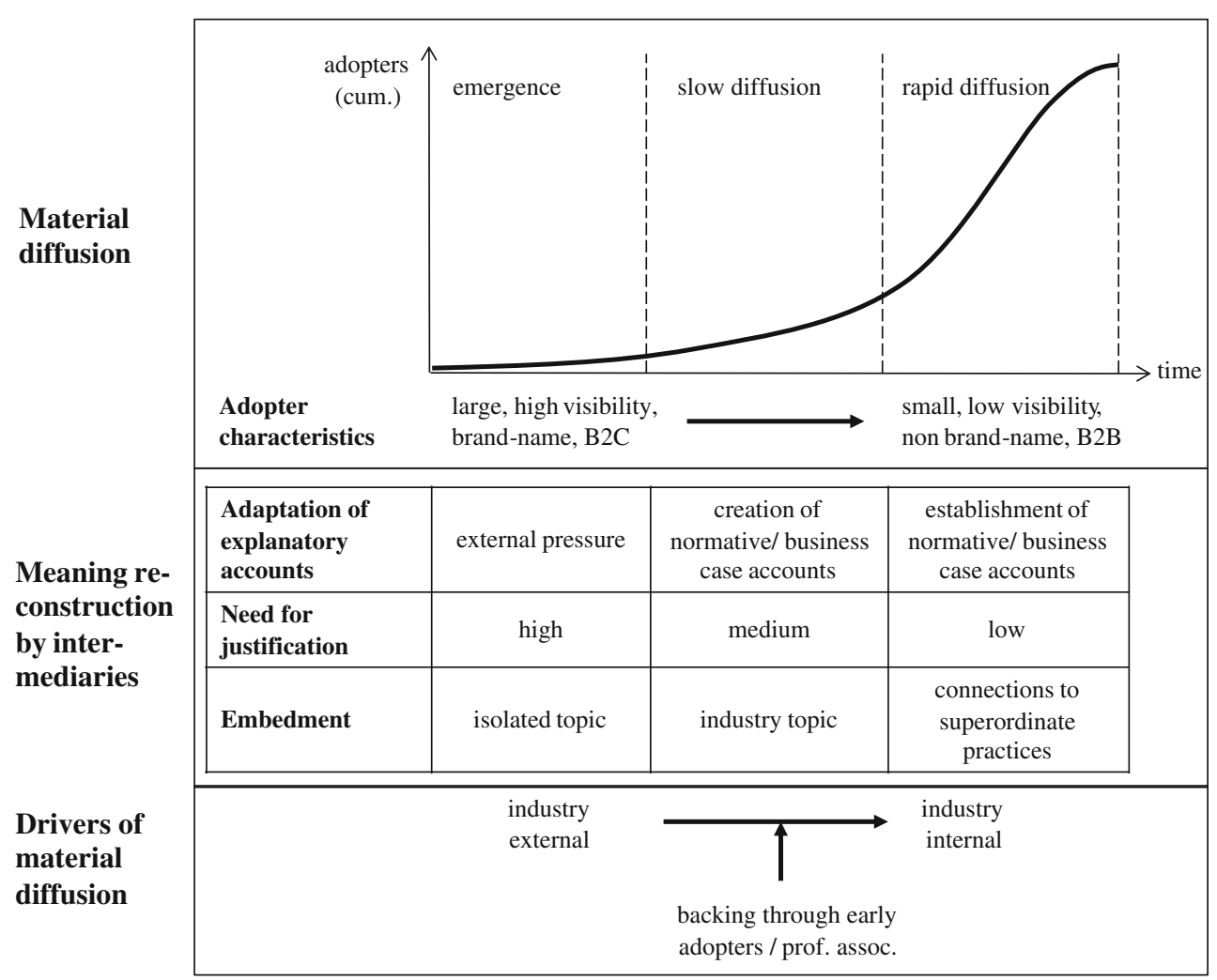

Fig. 5 Infomediary reporting and material diffusion of codes of conduct

practices in general and codes of conduct specifically and-most importantly-that indicators capturing changes in these meaning construction processes are systematically related to adoption decisions of firms.

\section{Theoretical Implications}

With the results of the qualitative and quantitative empirical analysis, I am able to provide a preliminary theoretical model capturing interrelations between changes in infomediary reporting and material diffusion of codes of conduct which details and extends the initial theoretical framework. Abstracting from my case study, this ideal type model suggests that three analytically dividable processes of meaning reconstruction by infomediaries might together constitute the basis for the broad material diffusion of codes of conduct specifically and potentially CSR practices in general (see Fig. 5): (1) an adaptation of explanatory accounts through which codes of conduct become infused with normative and economic value which resonates with the needs of those firms within an industry that are not directly affected by the external societal pressures that caused the emergence of the practice; (2) a declining need for justification which contributes to evoking the impression among potential adopters that codes of conduct have become a well accepted, legitimate practice within the industry and that ignoring it might yield negative social and/or economic consequences; and (3) an increasing embedment of discourses on codes of conduct into general industry discourses and discourses on related, higher-order practices (CSR as a larger phenomenon, sustainability), which increases the reach of respective articles within the industry and contributes to learning effects among potential adopters (e.g., concerning the "fit" of the practice for a larger CSR strategy).

Interestingly, taken together, these meaning reconstruction processes are indicative of a process in which drivers of code diffusion located outside of an industry are gradually replaced by drivers within the industry. While during the emergence and slow diffusion phase, the main driver of diffusion is external pressure (by NGOs, potential regulations), rapid diffusion of codes of conduct across larger parts of an industry for which external societal pressures play a minor role might rather be spurred by drivers within the industry (adaptation of accounts, cognitive institutionalization, learning, and peer pressure). In a similar vein - although without an explicit consideration of the role of media-Chua and Rahman (2011) have hypothesized that the prevalence of codes of conduct evolves in three stages: institutional pressures, normative 
expectations, and imitation. Additionally, as has above been discussed in detail, qualitative evidence suggests that this process is not an automatism, but perpetuated by the backing of early adopters within the industry who-due to their influential position as members of infomediary organizations such as (in this case) trade associations-seem to contribute to translating external societal pressures into industry internal peer pressure. Figure 5 summarizes the theoretical model just described.

Although the theoretical model just presented is to a considerable extent based on empirical findings from an assessment of one specific CSR practice (codes of conduct), I believe that it might help to understand the role of discourses produced by infomediaries for the diffusion of a larger set of management practices. More specifically, I would argue that a large share of management practices that are nowadays summarized under the label "CSR" are characterized by the fact that during their emergence, these practices-from the perspective of their adopters-represent instruments for buffering societal pressures located outside of firms immediate industry environment. Nevertheless, these practices frequently diffuse across parts of industries for which these external pressures are of little relevance and the measurable economic outcomes they produce are disputable. The theoretical model developed here might thus help to understand the role of discourses produced by infomediaries like trade journals or professional groups for the material diffusion of other CSR practices than codes of conduct (e.g., reporting initiatives, pollution prevention standards).

Obviously, the preliminary theoretical model presented here exhibits overlaps with a number of prior works which constitute the basis for my initial theoretical framework. Existing research in the CSR field has conceptually (Deephouse and Heugens 2009) and empirically (Grafström and Windell 2011) assessed the role of infomediaries in constructing the meaning and relevance of CSR practices. Mazza and Alvarez (2000) as well as Vaara and Tienari (2002) have discussed the importance of the establishment of normative an economic rhetoric produced by professional media for the establishment of management practices and Greenwood et al. (2002) have analyzed specific role of professional groups as infomediaries. Green (2004) developed a theoretical model capturing interrelations between a declining need for discursive justification and material practices diffusion [also see Lamertz and Baum (1998)]. The potential effect of changing frames of reference has been discussed in prior research on interdiscursivity (Phillips et al. 2004) and analogies (Etzion and Ferraro 2010).

Nevertheless, my theoretical model transcends existing research in at least two ways: First, as I have outlined above, existing research assessing the role of infomediaries for the diffusion of CSR practices has so far concentrated on understanding changes in content produced by infomediaries without explicitly accounting for interrelations with patterns of material practice diffusion. The model presented here not only includes but also explicitly focuses on this latter aspect. Second, to our knowledge, the broader line of prior research on the diffusion of management practices has so far largely refused to combine-in one theoretical model and empirical assessment-arguments on interrelations among changes in explanatory accounts, frames of reference, and quantitative patterns of material practice diffusion.

\section{Discussion and Contributions}

Do changes in the way infomediaries like trade journals or professional associations report on CSR practices interrelate with decisions by organizations to adopt these practices? The results of this study contribute to answering this question as they indicate that a systematic relationship exists between the way infomediaries construct the meaning of codes of conduct and patterns of their material diffusion. Based on my findings and the theoretical model derived, I am thus able to provide a number of contributions to different strands of existing literature that are outlined in the following sections.

\section{Diffusion of Codes of Conduct}

First, the results of this study contribute to current research on the diffusion of codes of conduct as a specific phenomenon. Recent work by Long and Driscoll (2008) as well as Chua and Rahman (2011) has used institutional theory in order to conceptualize the emergence and diffusion of codes of conduct as a sequence of institutional pressures, followed by a developing consensus on the value of codes and wide adoption led by imitation. Although, with my empirical study, I am not able to sketch the complete conceptual models developed by the authors, my results provide - to my knowledge-the first empirical assessment of the diffusion of codes of conduct in light of their implicit propositions, especially with regards to "capturing a temporal quality to this process" (Long and Driscoll 2008, p. 186). My findings thereby support the theoretical proposition that codes of conduct mainly emerge as responses to external social pressures-coercive pressures in institutional theory terminology (DiMaggio and Powell 1983). At the same time, I find support for the established theoretical assumption that for their wider diffusion, a certain industry-level consensus, concerning the value of codes of conduct for firms that are not affected by the initial social pressures, and thus normative pressures, 
has to develop. More specifically, I find that the meaning that infomediaries attached to codes of conduct over time stabilized around both moral and business case justifications. Additionally, in my depiction of the meaning reconstruction process, I found qualitative evidence that the observable shift in the way codes of conduct were rationalized was backed by early adopters within the industry. This result suggests that adopting organizations themselves-especially early adopters-take a more active stance in the diffusion and eventual institutionalization process of codes of conduct than existing conceptual models would (Wetterberg 2007) suggest. Prominent early adopters might thus not only passively influence code diffusion in later periods through the fact that other firms start to mimic their behavior (Chua and Rahman 2011; DiMaggio and Powell 1983) but also actively promote codes of conduct, e.g., through their influential positions in boards of professional associations like the AVE studied here.

In sum, these findings and the resulting theoretical model I have outlined also raise intriguing questions concerning the sustainability of codes of conduct. The changing focus of discourses on codes of conduct I observe, one the one hand, seems to have the potential to resonate with the values and beliefs of a broad spectrum of firms within an industry and by this means to motivate firms to adopt codes of conduct. On the other hand, this discursive shift also seems to imply that the focus of interest becomes increasingly detached from the very core of the problem codes of conduct in this industry address, namely, exploitative working conditions, child labor, etc. As we have observed in the early periods of diffusion, the way these topics made their way into texts produced by infomediaries was often through reports on NGO campaigns and protests (classified as social pressures) which uncovered scandals in firms' global supply chains. The success of codes of conduct in terms of membership numbers we observe today may thus yield disputable consequences: While a growth in the number of western companies adopting codes might lead to improved working conditions for a larger scope of production plants, the attachment of a "business case" logic to this practice might concurrently imply that codes become part of firms' portfolio of other "regular" management practices, especially for firms that do not face pressures by NGOs. Interestingly, a similar shift from problem- to non-problem-focused legitimation, and by this means "naturalization" of an organizational practice, has been observed by Vaara and Tienari (2002) with respect to media discourses on Mergers and Acquisitions in Finland. It should thereby be kept in mind what we know from a long tradition of research in organizational theory: Such management practices are frequently adopted and abandoned like regular short-lived fashions (Abrahamson 1996; Kieser 1997). Future work could examine this proposition on the consequences of an attachment of "not problem related" meanings to codes of conduct.

\section{Diffusion of CSR Practices}

In terms of broader contributions, my results speak to recent work on the role of infomediaries in the development of CSR as a larger phenomenon. In a recent conceptual paper, Deephouse and Heugens (2009) have proposed that in their decision to adopt certain social issues, firms will be influenced by the intensity as well as content of coverage produced by infomediaries. This model has recently been taken up by Grafström and Windell (2011) in an empirical study on the way prominent business media report on CSR. With my study, I am able to demonstrate that the basic proposition on a direct relationship between the way infomediaries reconstruct the meaning of CSR practices and adoption dynamics within industries, that has so far not been tested empirically, seems to hold.

In this regard, the theoretical model I have derived additionally provides detailed insights on specific mechanisms that meaning reconstruction processes potentially influencing the adoption of CSR practices are driven by. Besides assessing accounts brought forward for justifying the engagement with codes of conduct, which has been done in a similar vein by prior work in the CSR field (Grafström and Windell 2011), I identified two further indicators that can be used when assessing processes of meaning reconstruction. First, in line with existing theoretical arguments on the relationship between language and processes of institutionalization (Green 2004), I explicitly accounted for the absence of certain arguments. This assessment of what is not said, to silences, often recommended as one step within content analysis (Bauer and Gaskell 2000), could provide important insights in assessments of discourses evolving around the diffusion of CSR practices. This study highlights that a thorough assessment of the meanings [e.g., strategic vs. ethical (Long and Driscoll 2008)] that become attached to CSR practices before the perceived necessity to provide accounts ceases helps to understand which conceptions of corporate responsibility eventually gain a status of "taken for grantedness" within industries or even whole societies (Deephouse and Suchman 2008). Second, my results demonstrate the importance of assessing how the connectedness or "interdiscursivity" (Phillips et al. 2004) of different discourses on CSR practices evolves. According to my findings, the chances for producers of discourses on certain CSR topics to gain attention-and more importantly to evoke substantial reactions by affected organizations- 
seem to be positively related to their ability to connect "their" specific topic to larger, eventually more prominent discourses. Both aspects of meaning (re)construction processes evolving around the diffusion of CSR practices might thus represent interesting conceptual as well as empirical starting points for future research that aims at assessing and understanding factors predicting outcomes of discussions on appropriate levels of corporate responsibility.

\section{Institutional Theory}

Finally, my findings contribute to existing conceptual and empirical assessments of diffusion from institutional theory. As has repeatedly been indicated by researchers like Strang and Meyer (1993), Strang and Soule (1998), and only recently Zilber (2008, p. 164), within this research a "conceptual as well as methodological dichotonomy" exists between empirical studies that assess diffusion as a material phenomenon (and thus concrete adoption patterns) and studies that assess meanings underlying diffusion (and thus mostly discourses). Only a few conceptual studies within the last years have started to contribute to closing this research gap [e.g., Green (2004), Phillips et al. (2004)], resulting in calls to "explore the interrelations between practices/structures and meanings" (Zilber 2008, p. 164). The study at hand attempts to contribute to bridging this divide in diffusion research-both theoretically and empirically.

Theoretically, I intended to bring together the two streams of research described above by formulating and testing propositions that explicitly account for the understudied relationship between meanings ascribed to organizational practices and patterns of their material diffusion. These propositions on the relationship between changes in explanatory accounts and frames of reference and patterns of material diffusion as well as the theoretical model I have deduced might thereby provide a conceptual starting point for future research that intends to conceptually bind together the two approaches to studying diffusion outlined above. Future work assessing material diffusion patterns might, for example, profit from complementing classical conceptual arguments and hypotheses from structural diffusion research-e.g., on the influence of social and spatial proximity or interlocking directorates-by accounting for the parallel and direct or indirect effect of changes in meaning (re)construction by relevant infomediaries.

Such a combination of "classical" arguments on predictors for practice adoption with propositions on the influence of changes in industry-level discourses also represents a methodological challenge. I believe that my approach to quantifying changes in meaning (re)construction might thereby contribute to bridging the gap described above, because it facilitates attempts to integrate both views using one conceptual and eventually even formal diffusion model (e.g., Strang and Tuma (1993)). Such a methodological integration could help to account for competing "adopter-centric" (Strang and Soule 1998, p. 268) and cultural explanations for diffusion in one empirical setting. The approach to identifying, quantifying, and interpreting changes in contents produced by infomediaries based on definable indicators used in this paper might serve as the first blueprint for studies assessing similar phenomena in other industries or with respect to other practices.

\section{Limitations and Conclusions}

The presented results are constrained in their explanatory power in at least two ways. First, by analyzing solely publicly available discourses, the study is not able to assess the-potentially differing-discourses evolving around codes of conduct taking place via non-public communication channels. Thus, especially intra-industry mechanisms like lobbying, power struggles, or individual agreements between actors operating "underneath the surface" which could provide additional insights with respect to the research question were not taken into consideration. Second, the methodological layout of my study as a case study implies certain limitations in terms of the generalization of the implications. This study is located in a European institutional context that has been described to differ from, for instance, Anglo-American contexts in terms of the role of governmental influences. As I have outlined, the standardized BSCI code of conduct has, at its emergence, been indirectly supported by a governmental organization (the former GTZ). Indirect governmental support can have created some kind of "baseline legitimacy" for this practice that we might not find in other institutional contexts such as the United States. Comparative case studies can clarify whether this idiosyncratic feature of this case might imply specific limits in terms of generalization.

In spite of these limitations, my study contributes to generating a deeper understanding for the establishment of systems of private self-regulation specifically and CSR practices generally. The findings highlight that in order to explain the recent spread of practices relating to the social responsibility of profit-oriented firms, it is necessary to understand the cultural processes through which individual and organizational actors come to accept certain ideas about the relationship between corporations and society as a social reality. Interest-driven actors thereby partake in a "cultural struggle" (Hoffman and Ocasio 2001, p. 414) and by this means influence how certain ideas develop. Although such ways of exercising influence by certain societal groups are more subtle and harder to decipher than 
direct power-driven interventions, they can yield considerable societal impacts. The results of this study help to understand the way infomediaries as social actors partake in shaping a socially constructed reality in which certain practices and underlying ideas about the relationship between societal and corporate sectors can establish and "stick," while others are sorted out.

Acknowledgments I gratefully acknowledge the support of this research project by the German Research Foundation (Deutsche Forschungsgemeinschaft, DFG). I thank Dominika Wruk, Michael Woywode, Achim Oberg as well as the anonymous reviewers for insightful comments on previous drafts of this manuscript. During the completion of this paper I also benefited from discussions at the Comparative Systems Workshop at Stanford University, the New Institutionalism Workshop 2009 in Naples, the EGOS 2009 Colloquium in Barcelona and the Academy of Management Annual Meeting 2010 in Montréal.

Table 5 Issue markers

(bsci OR ave OR (code* I/2 conduct) OR social standard* OR arbeitsbedingungen OR (dritte* I/1 welt) OR (3. I/1 welt) OR ngo OR nro OR nongovernmental OR NOTregierungs* OR CCC OR (clean AND clothes AND campaign) OR (kampagne AND für AND saubere AND kleidung) OR (selbstverpflichtung* AND freiwillig*) OR (ilo NOT ifw@ilo.de) OR sai OR sa8000 OR socam OR (business AND social AND compliance) OR kodex OR verhaltenskodex OR kernarbeitsnorm*)

\section{Appendix 1}

See Table 5 .

\section{Appendix 2}

See Table 6.

Table 6 Example for category "account” [pressure]

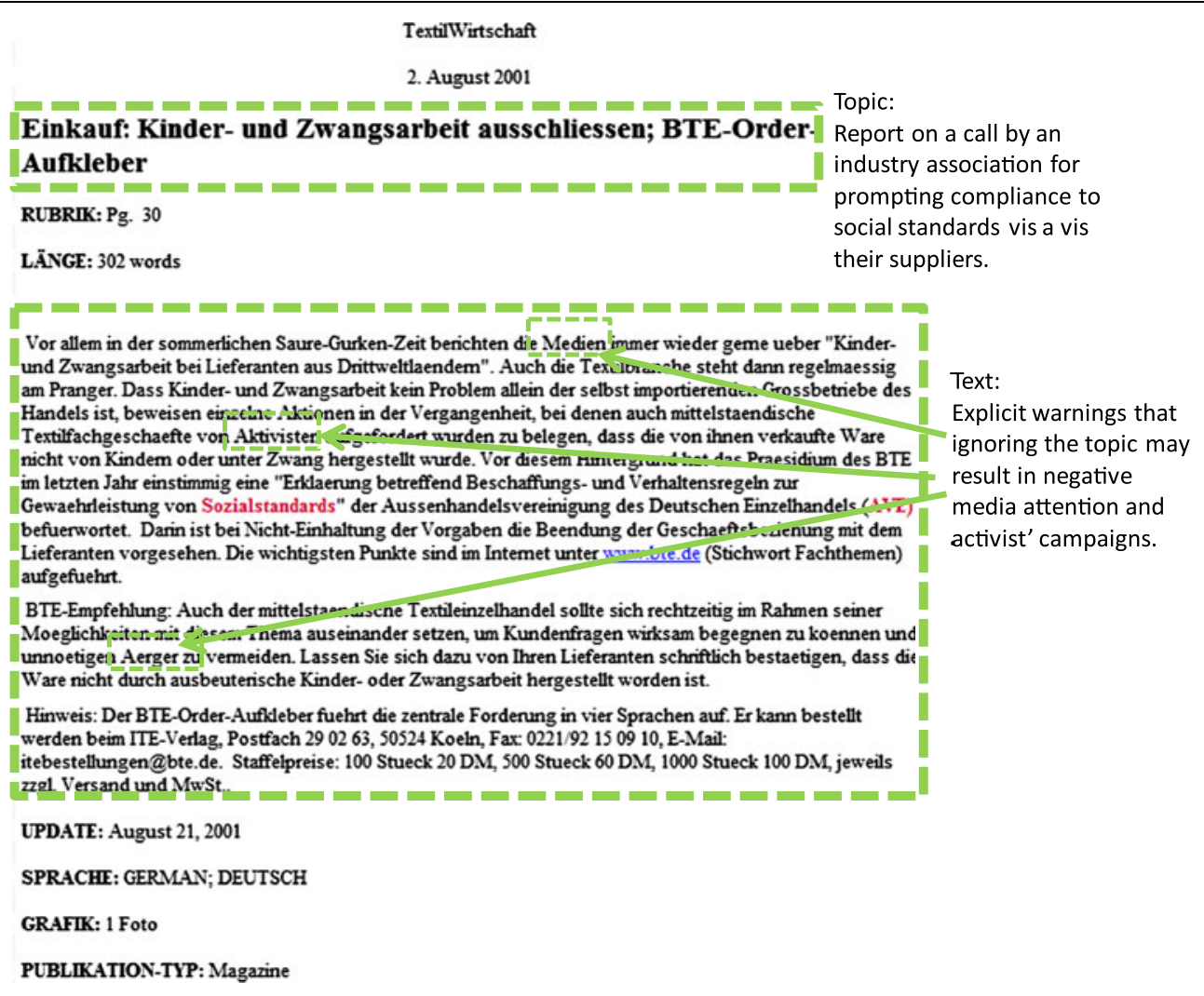

The examples of coded texts and text units in appendices 2-3 are presented in their original German form in order to guarantee a genuine presentation of coded material. English translations of respective text examples can, on request, be provided by the authors 


\section{Appendix 3}

See Table 7.

Table 7 Example for category "no account"

\section{TextilWirtschaft}

$\begin{array}{ll}\text { Fair\&Human setzt auf Sozialstandard; Gewerkschaftliche } & \text { Topic: } \\ \begin{array}{ll}\text { Zusammenschluesse als Voraussetzung } & \text { Report on startup that } \\ \text { offers support (e.g. a } & \text { code of conduct) for } \\ \text { AUTOR: Kem, Jana } & \text { firms that aim at } \\ \text { RUBRIK: Business Industrie; S. } 42 & \text { improving working } \\ \text { LÄNG: } 164 \text { words } & \text { conditions. }\end{array}\end{array}$

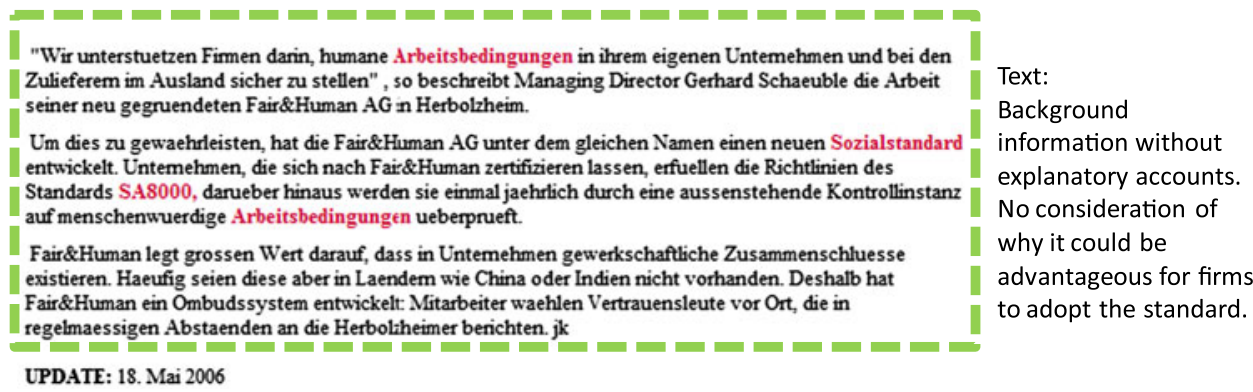

\section{Appendix 4}

See Table 8.

Table 8 German companies that became subject to campaigns by the CCC

\begin{tabular}{|c|c|c|c|c|c|c|c|c|c|c|c|c|c|c|c|c|}
\hline \multirow[t]{2}{*}{ Company } & \multirow{2}{*}{$\begin{array}{l}\text { Top } 100 \\
\text { suppliers } \\
\text { and } \\
\text { retailers }^{\mathrm{a}}\end{array}$} & \multicolumn{14}{|c|}{ CCC campaigns ${ }^{\mathrm{b}}$} & \multirow{2}{*}{$\begin{array}{l}\text { Cam- } \\
\text { paign } \\
\text { years }\end{array}$} \\
\hline & & 1997 & 1998 & 1999 & 2000 & 2001 & 2002 & 2003 & 2004 & 2005 & 2006 & 2007 & 2008 & 2009 & 2010 & \\
\hline Adidas & $X$ & $X$ & $X$ & $\mathrm{X}$ & $X$ & $\mathrm{X}$ & $\mathrm{X}$ & $\mathrm{X}$ & $\mathrm{X}$ & $X$ & $X$ & $X$ & $X$ & $X$ & $\mathrm{X}$ & 14 \\
\hline Puma & $X$ & & & & $\mathrm{X}$ & $X$ & $\mathrm{X}$ & $\mathrm{X}$ & $\mathrm{X}$ & $X$ & $X$ & $X$ & $X$ & $X$ & $X$ & 11 \\
\hline $\begin{array}{l}\text { Karstadt/ } \\
\text { Arcandor }\end{array}$ & $X$ & $\mathrm{X}$ & & & $\mathrm{X}$ & $\mathrm{X}$ & $\mathrm{X}$ & $\mathrm{X}$ & $\mathrm{X}$ & $\mathrm{X}$ & $X$ & $\mathrm{X}$ & $X$ & & & 10 \\
\hline Otto $\mathrm{GmbH}$ & $\mathrm{X}$ & $\mathrm{X}$ & $\mathrm{X}$ & $\mathrm{X}$ & & $\mathrm{X}$ & $\mathrm{X}$ & $\mathrm{X}$ & & $X$ & & & $\mathrm{X}$ & & & 8 \\
\hline $\mathrm{H} \& \mathrm{M}$ & $X$ & & $X$ & & & $X$ & & $\mathrm{X}$ & $\mathrm{X}$ & $X$ & $X$ & $X$ & & & & 6 \\
\hline C\&A & $X$ & $\mathrm{X}$ & $\mathrm{X}$ & $X$ & & & & $\mathrm{X}$ & & & & & $X$ & & & 5 \\
\hline Tchibo & $X$ & $\mathrm{X}$ & & & & & & & $X$ & $X$ & $X$ & $X$ & & & & 5 \\
\hline Steilmann & & & & $\mathrm{X}$ & & & & & $\mathrm{X}$ & $\mathrm{X}$ & $X$ & $X$ & & & & 5 \\
\hline Aldi & $X$ & $X$ & & & & & & & & $X$ & & $X$ & $X$ & $X$ & $\mathrm{X}$ & 5 \\
\hline Zara (Inditex) & $\mathrm{X}$ & & & & & & & & $\mathrm{X}$ & $X$ & $X$ & $X$ & & & & 4 \\
\hline Lidl & $X$ & & & & & & & & & $\mathrm{X}$ & & & $X$ & $X$ & $\mathrm{X}$ & 4 \\
\hline Metro & $\mathrm{X}$ & & & & & & & $\mathrm{X}$ & & & & & & $X$ & $\mathrm{X}$ & 3 \\
\hline Triumph & & $\mathrm{X}$ & & & & & & & & & & & & & $\mathrm{X}$ & 2 \\
\hline New Yorker & $X$ & & & & & & & & & & $X$ & $X$ & & & & 2 \\
\hline $\begin{array}{l}\text { KiK } \\
\text { (Tengelmann) }\end{array}$ & $\mathrm{X}$ & & & & & & & & & & & & $X$ & $\mathrm{X}$ & & 2 \\
\hline
\end{tabular}


Table 8 continued

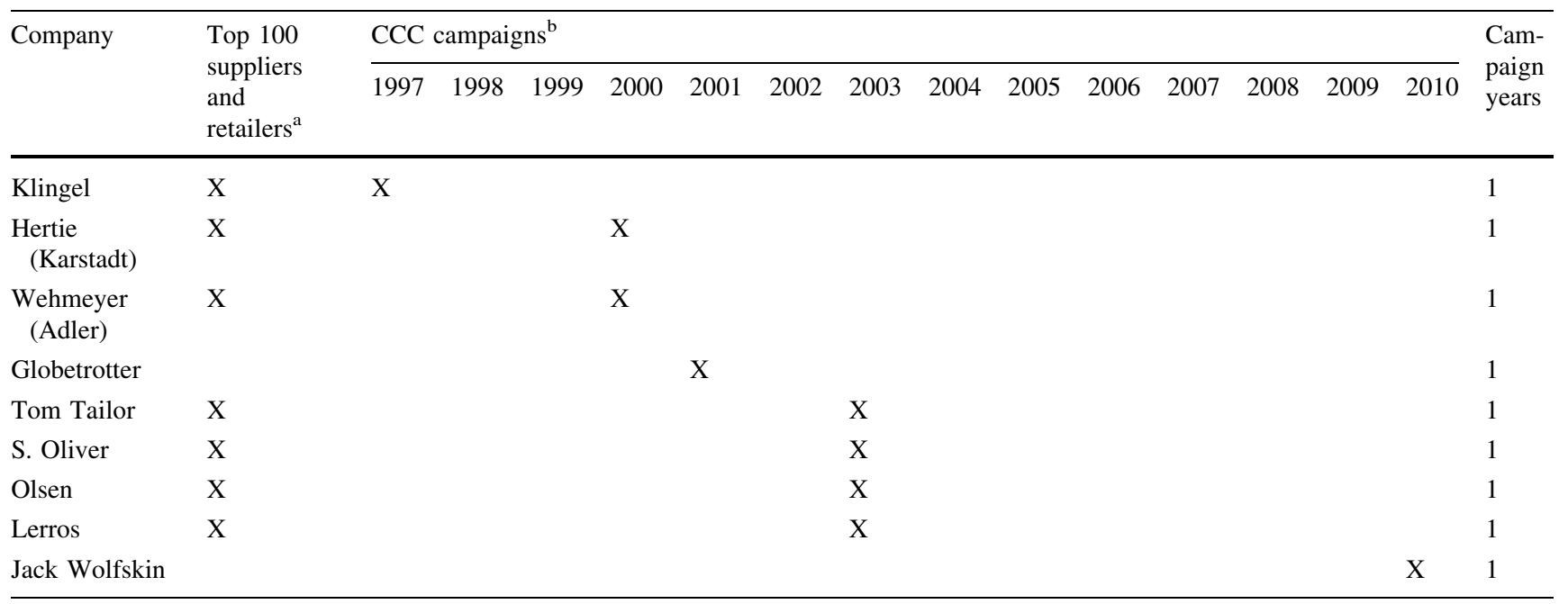

${ }^{a}$ Whether the company belongs to the top 100 German textile and apparel retailers and suppliers

b Whether the company name has been mentioned in a report by the German division of the CCC within the given year (archival material from http://www.saubere-kleidung.de)

\section{References}

Abrahamson, E. (1996). Management fashion. Academy of Management Review, 21(1), 254-285.

Abrahamson, E., \& Fairchild, G. (1999). Management fashion: Lifecycles, triggers, and collective learning processes. Administrative Science Quarterly, 44, 708-740.

Alvarez, J. L., Mazza, C., \& Strandgaard Pedersen, J. (2005). The role of mass media in the consumption of management knowledge. Scandinavian Journal of Management, 21, 127-132.

Bansal, P. (2005). Evolving sustainably: A longitidunal study of corporate sustainable development. Strategic Management Journal, 26, 197-218.

Bartley, T. (2007). Institutional emergence in an era of globalization: The rise of transnational private regulation of labor and environmental conditions. American Journal of Sociology, 113(2), 297-351.

Bauer, M. W., \& Gaskell, G. (2000). Qualitative researching with text, image and sound: A practical handbook for social research. London: Sage.

Bauer, M. W., Gaskell, G., \& Allum, N. C. (2002). Quality, quantity and knowledge interests: Avoiding confusions. In M. W. Bauer \& G. Gaskell (Eds.), Qualitative researching with text, image and sound. A practical handbook (2nd ed., pp. 3-18). London: Sage Publications.

Benford, R. D., \& Snow, D. (2000). Framing processes and social movements: An overview and assessment. Annual Review of Sociology, 26, 611-639.

Berger, P., \& Luckmann, T. (1966). The social construction of reality. A treatise in the sociology of knowledge. Garden City, NY: Anchor Books.

Bondy, K., Matten, D., \& Moon, J. (2004). The adoption of voluntary codes of conduct in MNCs: A three-country comparative study. Business and Society Review, 109(4), 449-477.

Braun, R., \& Gearhart, J. (2004). Who should code your conduct? Trade union and NGO differences in the fight for labor rights. Development in Practice, 14(1-2), 183-196.

BSCI (2012). Retrieved May 11, 2011, from http://www.bsci-intl.org.

Burns, L. R., \& Wholey, D. R. (1993). Adaption and abandonment of matrix management programs: Effects of organizational characteristics and interorganizational networks. Academy of Management Journal, 36(1), 105-138.

Carroll, C. E., \& McCombs, M. (2003). Agenda-setting effects of business news on the public's images and opinions about major corporations. Corporate Reputation Review, 6, 36-46.

Chua, F., \& Rahman, A. (2011). Institutional pressures and ethical reckoning by business corporations. Journal of Business Ethics, 98, 307-329.

Creed, W. E., Langstraat, J. A., \& Scully, M. A. (2002). A picture of the frame: Frame analysis as technique and as politics. Organizational Research Methods, 5(1), 34-55.

Czarniawska, B., \& Joerges, B. (1996). Travel of Ideas. In B. Czarniawska \& G. Sévon (Eds.), Translating Organizational Change (pp. 13-48). Berlin, NY: deGruyter.

Deephouse, D. L., \& Heugens, P. P. (2009). Linking social issues to organizational impact: The role of infomediaries and the infomediary process. Journal of Business Ethics, 86, 541-553.

Deephouse, D. L., \& Suchman, M. (2008). Legitimacy in organizational institutionalism. In R. Greenwood, C. Oliver, R. Sudaby, \& K. Sahlin (Eds.), The sage handbook of organizational institutionalism (pp. 49-77). London: SAGE.

DiMaggio, P. J., \& Powell, W. W. (1983). The iron cage revisited: Institutional isomorphism and collective rationality in organizational fields. American Sociological Review, 48(2), 147-160.

Donati, P. R. (1992). Political discourse analysis. In M. Diani \& R. Eyerman (Eds.), Studying collective action (pp. 136-167). London: Sage Publications.

Egels-Zandén, N., \& Wahlqvist, E. (2007). Post-partnership strategies for defining corporate social responsibility: The business Social compliance initiative. Journal of Business Ethics, 70, 175-189.

Eisenhardt, K. M. (1989). Building theories from case study research. Academy of Management Journal, 14(4), 532-550.

Elliot, K. A., \& Freeman, R. B. (2001). White hats or Don Quixotes? Human rights vigilantes in the global economy. Cambridge: NBER Working Paper Series.

ETI. (2011). Retrieved May, 5, 2011, from http://www.ethicaltrade.org.

Etzion, D., \& Ferraro, F. (2010). The role of analogy in the institutionalization of sustainability reporting. Forthcoming in Organization Science, 21(5), 1092-1107. 
Fairclough, N. (1992). Discourse and social change. Cambridge: Polity Press.

Fiss, P. C., \& Zajac, E. J. (2006). The symbolic management of strategic change: Sense giving via framing and decoupling. Academy of Management Journal, 49(6), 1173-1193.

FLA. (2011). Retrieved May, 11, 2011, from http://www.fairlabor. org.

Fombrun, C., \& Van Riel, C. (1997). The reputational landscape. Corporate Reputation Review, 1(12), 5-13.

Gatto, A. (2011). Multinational enterprises and human rights: Obligations under EU law and international law. Cheltenham: Edward Elgar.

Gond, J.-P., \& Palazzo, G. (2008). The social construction of the positive link between corporate social and financial performance. In:Academy of Management Conference Best Paper Proceedings.

Grafström, M., \& Windell, K. (2011). The role of infomediaries: CSR in the business press during 2000-2009. Journal of Business Ethics, 103, 221-237.

Green, S. E. (2004). A rhetorical theory of diffusion. Academy of Management Journal, 29(4), 653-669.

Green, S. E., Li, Y., \& Nohria, N. (2009). Suspend in self-spun webs of significance: A rhetorical model of institutionalization and institutionally embedded agency. Academy of Management Journal, 52(1), 11-36.

Greenwood, R., Suddaby, R., \& Hinings, C. R. (2002). Theorizing change: The role of professional associations in the transformation of institutionalized fields. Academy of Management Journal, 45(1), 59-80.

Greven, T., \& Scherrer, C. (2005). Globalisierung gestalten. Weltökonomie und soziale Standards. Bonn: Bundeszentrale für politische Bildung.

Hamilton, L. C. (2008). Statistics with STATA: Version 10 (Vol. 7). Belmont: Brooks/Cole.

Hardy, C., Lawrence, T., \& Grant, D. (2005). Discourse and collaboration: The role of conversations and collective identity. Academy of Management Review, 30(1), 1-20.

Hartley, J. (2009). Case Study Research. In C. Cassell \& G. Symon (Eds.), Essential guide to qualitative methods in organizational research (pp. 323-333). London: Sage.

Hirsch, P. M. (1972). Processing fads and fashions: An organizationset analysis of cultural industry systems. American Journal of Sociology, 77(4), 639-659.

Hirsch, P. M. (1986). From ambushes to golden parachutes: Corporate takeovers as an instance of cultural framing and institutional integration. American Journal of Sociology, 91(4), $800-837$.

Hiss, S. (2009). From implicit to explicit corporate social responsibility: Institutional change as a fight for myths. Business Ethics Ouarterly, 19(3), 433-451.

Hoffman, A. J., \& Ocasio, W. (2001). Not all events are attended equally: Toward a middle-range theory of industry attention to external events. Organization Science, 12(4), 414-434.

Jonsson, S., Greve, H. R., \& Fujiwara-Greve, T. (2009). Undeserved loss: The spread of legitimacy loss to innocent organizations in response to reported corporate deviance. Administrative Science Quarterly, 54, 195-228.

Kaptein, M. (2004). Business codes of multinational firms: What do they say? Journal of Business Ethics, 50, 13-31.

Kaptein, M., \& Schwartz, M. (2007). The effectiveness of business codes: A critical examination of existing studies and the development of an integrated research model. Rotterdam: ERIM Report Series Research in Management.

Kaptein, M., \& Wempe, J. (2002). The balanced company: A theory of corporate integrity. Oxford: Oxford University Press.

Kieser, A. (1997). Rhetoric and myth in management fashion. Organization, 4, 49-74.
Kjær, P., \& Langer, R. (2005). Infused with news value: Management, managerial knowledge, and the institutionalization of business news. Scandinavian Journal of Management, 21, 209-233.

Lamertz, K., \& Baum, J. A. (1998). The legitimacy of organizational downsizing in Canada: An analysis of explanatory media accounts. Canadian Journal of Administrative Sciences, 15(1), 93-107.

Long, B. S., \& Driscoll, C. (2008). Codes of ethics and the pursuit of organizational legitimacy: Theoretical and empirical contributions. Journal of Business Ethics, 77, 173-189.

Margolis, J. D., \& Walsh, J. P. (2003). Misery loves companys: Rethinking social initiatives by business. Administrative Science Quarterly, 48, 268-305.

Martin, R. L. (2002). The virtue matrix. Calculating the return on corporate social responsibility. Harvard Business Review, 80(3), 68-75.

Mazza, C., \& Alvarez, J. L. (2000). Haute couture and prêt-à-porter: The popular press and the diffusion of management practices. Organization Studies, 21(3), 567-588.

McCombs, M. E., \& Shaw, D. L. (1972). The agenda-setting function of mass media. The Public Opinion Quarterly, 36(2), 176-187.

Meyer, R. E. (2004). Globale Managementkonzepte und lokaler Kontext. Wien: WUV Universitätsverlag.

Meyer, J. W., \& Rowan, B. (1977). Institutionalized organizations: Formal structure as myth and ceremony. The American Journal of Sociology, 83(2), 340-363.

Mills, W. C. (1940). Situated actions and vocabularies of motive. American Sociological Review, 5(6), 904-913.

O'Rourke, D. (2003). Outsourcing regulation: Analyzing nongovernmental systems of labor standards and monitoring. The Policy Studies Journal, 31(1), 1-29.

Phillips, N., Lawrence, T. B., \& Hardy, C. (2004). Discourse and institutions. Academy of Management Review, 29(4), 635-652.

Powell, W. W., \& DiMaggio, P. J. (1991). The new institutionalism in organizational analysis. Chicago: University of Chicago Press.

Rao, H. (1998). Caveat emptor: The construction of nonprofit consumer watchdog organizations. American Journal of Sociology, 103(4), 912-961.

Sahlin, K., \& Wedlin, L. (2008). Circulating ideas: Imitation, translation and editing. In R. Greenwood, C. Oliver, K. Sahlin, \& R. Suddaby (Eds.), The sage handbook of organizational institutionalism. London: Sage Publications.

Scarbrough, H., Robertson, M., \& Swan, J. (2005). Professional media and management fashion: The case of knowledge management. Scandinavian Journal of Management, 21, 197-208.

Selznick, P. (1957). Leadership in administration. New York: Harper \& Row.

Strang, D. (1997). Managerial discourse on quality circles as an organizational innovation. Toronto: Paper presented at the 1997 meetings of the American Sociological Association.

Strang, D., \& Meyer, J. W. (1993). Institutional conditions for diffusion. Theory and Society, 22, 487-511.

Strang, D., \& Soule, S. A. (1998). Diffusion in organizations and social movements: From hybrid corn to poison pills. Annual Review of Sociology, 24, 265-290.

Strang, D., \& Tuma, N. B. (1993). Spatial and temporal heterogeneity in diffusion. American Journal of Sociology, 99(3), 614-639.

Suchman, M. C. (1995). Managing legitimacy: Strategic and institutional approaches. Academy of Management Review, 20(3), 571-610.

Tolbert, P. S., \& Zucker, L. (1996). The institutionalization of institutional theory. In S. R. Clegg, C. Hardy, \& W. R. Nord (Eds.), Handbook of organization studies (pp. 175-191). London: Sage Publications.

TZ, G. (2002). Sozialstandards in der Weltwirtschaft. Eschborn: Deutsche Gesellschaft für Technische Zusammenarbeit. 
Vaara, E., \& Tienari, J. (2002). Justification, legitimization and naturalization of mergers and acquisitions: A critical discourse analysis of media texts. Organization, 9(2), 275-304.

Vaara, E., \& Tienari, J. (2009). A discursive perspective on legitimation strategies in multinational corporations. Academy of Management Review, 33(4), 939-985.

Weaver, G. R., Trevino, L. K., \& Cochran, P. L. (1999). Corporate ethics practices in the mid 1990s: An empirical study of Fortune 1000. Journal of Business Ethics, 18, 283-294.

Wetterberg, A. (2007). Concept versus content: The institutionalization of labor self-regulation in the global apparel industry. Berkeley: University of California.
Wick, I. (2005). Workers' tool or PR ploy? A guide to codes of international labour practice. Bonn: Friedrich Ebert Stiftung.

Yin, R. K. (1994). Enhancing the quality of case studies in health services research. Health Service Research, 34(5), 1209-1224.

Zilber, T. B. (2008). The work of meanings in institutional processes and thinking. In R. Greenwood, C. Oliver, K. Sahlin, \& R. Suddaby (Eds.), The SAGE handbook of organizational institutionalism (pp. 151-169). London: Sage.

Zucker, L. G. (1977). The role of institutionalization in cultural persistence. American Sociological Review, 42(5), 726-743. 